\title{
Tükör által
}

\section{A nyugati filozófiai tradíció szerepe a Meiji-megújulás önértelmezésében ${ }^{1}$}

„A világtörténelem keletröl nyugatra megy; mert Európa teljességgel vége a világtörténetnek, Ázsia a kezdete."

G.W.F. Hegel ${ }^{2}$

\begin{abstract}
A kérdés
A mindenkori Japánban születő, a konfuciánus tanításhoz, a buddhizmushoz, illetve a belső keletkezésü japán gondolkodási mintákhoz kötődő müvek öszszességét korunkban gyakran emlegetik ,japán filozófia”-ként. ${ }^{3}$ Abban persze e terminus használói is egyetértenek, hogy a buddhista iskolaalapítók múvei vagy a bushi erénytanhoz kapcsolódó Tokugawa-kori (1600-1867) munkák csak a terminus igen tág értelmében nevezhetők „filozófiai” írásoknak, amennyiben a japán gondolkodók a Tokugawa-kor utolsó szakaszában, elsősorban pedig a Meiji-kor (1868-1912) elején ismerkednek meg azzal a nyugati hagyománnyal, fogalmi rendszerrel, amelyet klasszikus értelemben így nevezünk. Anélkül, hogy ezen a ponton csatlakoznék az arról szóló vitához, mennyiben (nem) tekinthető „filozófiainak” a japán gondolkodástörténeti hagyomány, fontos leszögezni, hogy e címke alkalmazásának tipikusan két (kimondott vagy kimondatlan) oka van: a fogalmi elemzés megkönnyítése, ponto-

$1 \cong$ AZ EMBERI ERŐFORRÁSOK MINISZTÉRIUMA ÚNKP-16-3 KÓDSZÁMÚ ÚJ NEMZETI KivÁlósÁg PROGRAmJÁNAK TÁMOGATÁSÁVAl KÉSZÜLT. A tanulmány korábbi, a Meiji-kor eleji japán filozófiai fordítások szóhasználatát vizsgáló írásom folytatása. Ezúton köszönöm meg a tanulmány elkészítése során nyújtott segítséget Szabó Balázsnak és Várnai Andrásnak.

2 Hegel 1979: 192.

3 Az elemzések köréből eklatáns példa Blocker-Starling 2001.
\end{abstract}


sabban az elemzés - a szó európai értelmében véve - fogalmivá tétele és/vagy az a szándék, hogy az adott hagyományt mint filozófiát az ismert és elfogadott tradíciókkal egy szinten állóként tüntessék fel. (E szándék mögött a szerzők azon előfeltevése húzódik meg, hogy az olvasó azt fogja a saját hagyományával egy szinten állóként elfogadni, ami arra nagymértékben hasonlít. $\left.{ }^{4}\right)$ Számomra itt az utóbbi aspektus bír kiemelt jelentőséggel abban az értelemben - és épp ezért nem térek ki a korábbi évszázadok japán gondolkodástörténetének a „besorolhatóságát” érintő kérdésekre -, hogy tárgyam a Meiji-megújulás ${ }^{5}$ gondolkodóinak saját Japán-képe, amelyet az önfelismerés-önkritikaönaffirmáció hármasának sajátos belső feszültsége jellemez. A következőkben e feszültség okait mutatom be, választ keresve arra a kérdésre, miként alakulnak ki ebből a többszörös ellentétből olyan koherens szemléletmódok, amelyek már valóban csak ,japán filozófiaként”, vagyis japán (vallási, bölcseleti, erénytani) és nyugati (a szó klasszikus értelmében filozófiai) előzményeikkel együtt érthetők meg.

Azt a kettősséget érzékeltetendő, amely a keleti bölcseleti formák és a nyugati filozófia viszonyában megmutatkozik, álljanak itt Kuwaki Genyoku 桑木厳翼 (1874-1946), a XX. század egyik neves japán eszmetörténészének sorai.

„[A] filozófia [tetsugaku 哲学] vagy Indiában jön létre, s így indiai filozófiává válik, vagy Kínában jön létre, s így kínai filozófiává válik, különböző [filozófiákká], de az úgynevezett »filozófia« [firosofia フィロソフィア] Görögországban jön létre, s folytatódván a modern Európa egyes országaiban különböző formákban fejlődik tovább. Amit e »filozófia« rendszerének nevezünk, ma angol, német, francia típusaiban [fū 風] kisebb-nagyobb különbségekkel, de nagyjából azonos forrásból ered, s [irányzatainak] közös jellemzői vannak. Ez a »filozófia« kerül be Japánba is, így újabb sajátosságokat öltve magára. Minthogy ez válik a jelen, illetve a jövő filozófiájává [tetsugaku], a »filozófia« [firosofia] rendszerének japán filozófiai [ága] lesz. Vannak, akik úgy gon-

4 Ezen előfeltevés egyik legérzékletesebb és legismertebb példáját a kínai bölcselet kontextusában találjuk, jelesül Fung Yu-lan kínai filozófiatörténetének „,nyugatiasított” angol változatában (Fung 1966).

5 A „Meiji-megújulás” mint a Meiji ishin 明治維新 szókapcsolat fordítása melletti érvekhez lásd Takó 2017: 156. 
dolják, ez a valami nem japán, hanem nyugati, ám a Japánban létrejövő »filozófia« [firosofia] japán filozófiának [tetsugaku] tekinthető."6

A tetsugaku 哲学 terminus a philosophy, Philosophie stb. nyugati terminusok fordításaként Nishi Amane 西周 (1829-1897) szóalkotása, és a Meiji-kor elején jött létre. ${ }^{7}$ Amikor tehát Kuwaki ezt a megjelölést keleti gondolkodásmódokra használja, egyfelöl egy Japán számára modern fogalmat vetít vissza több évezred távlatába. Csakhogy amikor a görög és az ebből kialakuló európai filozófia kerül szóba, világos megkülönböztetést tesz firosofia és tetsugaku között, vagyis úgy tünik, mintha a filozófia szó fordításaként születő tetsugakunak más jelentése volna, mint saját eredetijének. Valójában Kuwaki itt úgy használja a tetsugaku megjelölést bármiféle gondolkodástörténeti alakzatra, ahogyan az európaiak saját terminusukat, a „filozófiá”-t, miközben az európai filozófia mint egységes hagyomány firosofia lesz. A kérdés, nyugati vagy japán fogalom-e a tetsugaku, a későbbiekben számos alakban tér vissza.

\section{„Saját” és „más”}

Amikor egy viszonylag egységes kultúra egy másikkal találkozik, rendszerint megjelennek az öneszmélés tipikus reakciói. Hatványozottan igaz ez, amikor a szóban forgó kultúra olyan, aránylag nagymértékü zártságban létezett, amilyenben Japán a XVII. század első felétől. Egészen sematikusan - Weberrel szólva ideáltipikusan - szemlélve e reakciónak két alapesete van, úgyszólván közös „tővel”: az önfelismerés mint a másik ,alatti” (fejletlenebb, lemaradó) és az önfelismerés mint a másik ,feletti” (fejlettebb, magasabb rendű) kul-

6「[…哲学が或はインドに於いて起ってインド哲学となり、或は支那に於い て起って支那哲学となり、色々になって居るのであるが、いわゆるフィロ ソフィアと云うものはギリシャに起って、そうして引続いて近世のヨーロ ッパ諸国に色々特別の形を以て発達している。即ちこのフィロソフィアの 系統と云うものは今日イギリス、ドイツ、フランスと云う風に多少変って 居るのですが、大体一つの根源から発して、共通点を有って居る。そのフ イロソフィアが日本にも伝って、そうして又特有の形を帯びて来た訳であ ります。それが即ち現代及将来の哲学となるので、これは即ちフィロソフ イアの系統の一つの日本の哲学であります。そう云うものは日本のもので なくして、西洋のものだ云うように考えて居る者がありますが、日本に出 来て居るフィロソフィアは日本の哲学だと思う。」(Kuwaki 2008: 79-80).

7 Kuwaki 2008: 137; TSHJ: 209-210. 
túráé. Akár a nagy földrajzi felfedezések korát ${ }^{8}$ vagy az európai Kína-, Japán-, India-recepciót, ${ }^{9}$ akár ,a Nyugat” japán befogadástörténetét ${ }^{10}$ vesszük példaként, úgy tünik, az összehasonlítás olyan skálákon történik, amelyek minden pontján egy és csakis egy kulturális elem helyezkedhet el, vagyis lehetséges, hogy az egyik kultúrkör a másikat bizonyos szempontból maga felettinek, más tekintetben elmaradottnak látja, de hogy tényleges azonosságot véljen felfedezni, az legalábbis rendkívül ritka. ${ }^{11} \mathrm{~A}$ másik mint más, és ezzel együtt a magunk mint más felismerése az „első itélet”, ez pedig tipikusan értékítélet, amelyet jellemzően a kiegyenlítés szándéka követ: a lemaradó saját kultúra építésére való törekvés (önkritika) vagy az elmaradottnak tekintett másik „elöre mozdításának” szándéka (önaffirmáció és a másik kritikája), ${ }^{12}$ amely számos esetben a Nyugatot jellemző, Edward Said-i értelemben vett „orientalizmusban" ölt formát. Morikawa - Luhmann nyomán - úgy fogalmaz, „[e]löször az összehasonlítás müvelete hoz létre különbözö [a reflektált kultúra értelmében vett] kultúrákat, melyek aztán egymással közvetítendők [miteinander vermittelt werden sollen], nem pedig fordítva". ${ }^{13}$ Ez a történelem számos pontján megfigyelhető „találkozási” folyamat, mint látható, mindig magában hordja az önfelismerés, az önkritika és az önaffirmáció lehetőségét, amelyek tehát semmiképp nem tekinthetők a japán Nyugat-recepció specifikumának. ${ }^{14}$ Ami a Nyugat japán befogadástörténetét sajátossá teszi, az említett elemek sajátos összefonódása.

A Meiji-megújulás talán legjellegzetesebb, de legalábbis legtöbbször emlegetett aspektusa Japán „nyugatiasodása/nyugatiasítása” volt, amely azzal járt együtt, hogy a nyugati államszerkezet, közoktatás, közigazgatás vagy épp az öltözködési szokások átvételének ,,szerencsétlen, de talán elkerülhetetlen mellékhatásaként”, írja Tobin, kialakult az „alárendeltség [inferiority] érzése,

8 Lásd Bitterli 1982, föként IV. fejezet.

9 Lásd Várnai 1973.

10 Lásd Takó 2017. és az ott hivatkozott műveket.

11 Természetesen az azonosság tételezése sem kizárt: Leibniz például egy szintre helyezi az európai és a kínai technikai mesterségeket, miközben azt is megjegyzi, hogy a teoretikus tudományokban Európa meghaladja Kínát, a hangsúly azonban a philosophia practicában mutatkozó európai lemaradáson van. Lásd Takó 2013: 139; Várnai 2015: 85.

12 Tipikus példa J. S. Mill interpretációja az indiai gyarmatosításról - lásd Takó 2016: 241-242.

13 Morikawa 2013: 58. A betoldás Morikawa jegyzetben adott kiegészítése.

14 Az alább bővebben vizsgált, a nacionalizmushoz kapcsolódó vonatkozásokhoz lásd Anderson híres ,az összehasonlítások kísértete” (the spectre of comparisons) elméletét (Anderson 2002, a terminushoz 229), vö. Niikura 2009: 58-60. 
melyet az okozott, hogy az orientalizáló Nyugat szemével tekintettek magukra”, így nem csak államszerkezeti elemeket és divatokat ,importáltak”, hanem „a nyugati értékeket, ízlést, illetve előítéleteket [is], beleértve a nem-Nyugat [non-West] etnocentrikus, koloniális lenézését" ${ }^{15}$ Ez a jellegzetes adaptációs hajlam két további sajátos mozzanattal fonódott össze. Az egyik a Tobin által „ön-egzotizációnak” nevezett jelenség másik oldala, jelesül az az „ön-orientalizáló" attitüd, hogy a japánok olyannak mutatkoznak, amilyennek a nyugati sztereotípiák értelmében „lenniük kell”. Vagyis, miközben küzdenek a negatív elóitéletek célpontját alkotó kulturális elemek kiiktatásáért, a nyugati elvárásokat kielégítendő fenntartják azt a látszatot, amely voltaképpen nem a valódi, hanem a Nyugat Japán-képében éló Japánt jellemzi. Ezáltal persze ismét olyan mintáknak felelnek meg, amelyek az európai müveltség szupremáciájából kiindulva „gyermekiesként” tekintenek a keleti kultúrákra, csak épp ez esetben nem gyermeki elmaradottságot, hanem egyfajta gyermeki bájt, ártatlan egyszerüséget, természetközeliséget vélnek felfedezni benne. ${ }^{16}$ Ugyanakkor, míg az ország megpróbált nemjapánná válni abban, amiben lenézték, és ,japánként" viselkedni abban, amihez ,a Nyugat” - sokszor tévesen - mint autentikusan japánhoz vonzódott, egyben megpróbált egységes japán nemzetténemzetállammá is válni: a legkülönbözőbb területeken tevékenykedő „értelmiségiek" - irodalmárok, konfuciánus tudósok, államférfiak, néprajzkutatók, gondolkodók - igyekeztek rátalálni arra, ami Japánt egységessé teszi, és az önkritikát önaffirmációval ellensúlyozza. Itt érkezünk el a számunkra központi jelentőségü kettősséghez: ahhoz, hogy miközben az elöbbi, szintén komplementer viszonyban álló attitüdök esetén Japán Európa tükrében nézett magára, egyedisége keresésében Európával szemben, de szintén európai minták szerint határozta meg magát - ezt a szemléletet nevezi Morikawa az orientalizmus párjaként „okcidentalizmusnak”. ${ }^{17}$ Ez az attitüd, egyfelől, hasonlóképpen kezeli a Nyugatot az ,úgy-nem-szabad-lennie” példájaként, ahogyan a Nyugat

15 Tobin 1992: 30

16 Vö. Tobin 1992: 30-31. Érzékletes példája az e mintáknak való megfelelésnek a századfordulós japán színtársulatok azon játéktechnikája, amelyet kifejezetten a nyugati közönség számára dolgoztak ki, és amelynek révén ,autentikusnak” tünő, de valójában nem a valódi japán színpadi tradíciót követő előadásokat hoztak létre (lásd Doma 2013: főként 90). Valamivel későbbi, de szintén igen érzékletes példa Eugen Herrigel esete, aki a buddhista gondolkodást és a japán harci müvészetet több művében is összekapcsolta, nemjapánként adva alapot egy olyan értelmezésnek, amely mára - ahogy Szabó fogalmaz - a „föleg nyugati szakirodalomban már szinte toposszá vált” (Szabó 2016: 45). 
orientalizmusa mint elmaradott, „fejletlen” alakzatot szemlélte a Keletet annak szimbólumaként, ami töle lényegileg idegen, vagyis amivel mint „,negatív tükörképével” szemben meghatározta magát. ${ }^{18}$ A Nyugattal szembeforduló és a saját hagyományt ideállá emelő gondolkodás azonban, másfelöl, ismét csak szorosan kapcsolódik a nyugati gondolkodáshoz, amennyiben a jelenét tekintve lenézett Kelet múltja - és ezen a ponton fonódik össze ez az aspektus az előzővel - a XIX. században a Nyugat romantikus visszavágyódásának tárgyává is vált. Azzá a hellyé, ,ahol az elveszett totalitás, a természettel való elveszett egység, az elveszett autentikus közösség és az istenhez, illetve az istenségekhez való helyes viszony fellelhető". ${ }^{19}$ Az e visszavágyódással átitatott neoromantika irodalmát a századfordulón széles körben olvasták Japánban a Mori Ōgaihoz 森鴎外 (1862-1922) hasonló, kiemelkedő fordítóknak köszönhetően, és ez ismét csak erősítette a saját hagyomány egyediségének érzetét a nyugati modernitással szemben, ezt az egyediségérzetet ugyanakkor egyre inkább ,nyugatias” formában, nyugati fogalmak és szemléletmódok révén rögzítették. ${ }^{20}$ A jelen tanulmány célja e többszörösen összetett viszony filozófiai kontextusban való megnyilvánulásainak a vizsgálata. $^{21}$

18 Morikawa a Nyugattól való keleti (japán) elhatárolódást a következő ellentétpárokban határozza meg: [nagy]város vs. vidék; [romlott] nő vs. [erényes] férfi; tömeg vs. elit; [pénzéhes] kereskedő vs. harcos; értelem vs. érzelem; szellem vs. lélek (a párok első tagja a nyugati, negatív sajátosságot, a második a vele szembehelyezett keletit jelenti; Morikawa 2013: 65).

19 Morikawa 2013: 65.

20 Mint látható, az „okcidentalizmus” aszimmetrikus viszonyban áll az orientalizmussal, amennyiben nem a Nyugat múltjával mint pozitívval állítja szembe saját jelenét, hanem a közelmúlt egy nyugati - föként a müvészeteket átitató - áramlata nyomán magasztalja föl saját múltját, hogy az újkori Nyugattal egy szintre emelkedjen.

21 Fontos megjegyezni, hogy bár a „filozófiai” jelző használata e korszakra vonatkozóan jogosult annyiban, hogy mivel a Meiji-kort egyebek mellett a nyugati minták tudatos követése jellemzi, az ekkor születő müvek explicit módon filozófiai munkák - a „filozófia(i)" terminus a következőkben igen tágan, filozófiai jellegü vagy indíttatású gondolkodásként értendő, hiszen itt éppúgy tudományos technikák, koncepciók, sémák átvételéről van szó, mint a Tokugawa-kori yōgaku 洋学 (,nyugati tudomány”) számos esetében, ez pedig szükségképpen hosszú folyamat. 


\section{Kokutai 國體}

Perry admirális „fekete hajóinak” érkezése (1853) előtt Japán önmeghatározásának fö viszonyítási pontját Kína jelentette. Mint Farkas hangsúlyozza, ${ }^{22}$ a kínai dominancia elutasítása már ebben a korszakban meghatározó volt, és fokozatosan vált uralkodóvá elöször a shushigakutól 朱子学, a Song-kori Kína meghatározó bölcseleti hagyományától eltávolodó gondolkodóknál ${ }^{23}$ (Itō Jinsai 伊藤仁斎 [1627-1705], Ogyū Sorai 荻生徂徠 [1666-1728 $]^{24}$ ), majd a „saját”, belső keletkezésü japán hagyomány elsődlegességét hangsúlyozó kokugaku 国学, illetve a konfuciánus, Song-konfuciánus és belső keletkezésű japán hagyományokat sokkal inkább összekapcsolva kezelő Mitogaku (水戸学 „,mitói tudomány” ${ }^{25}$ ) képviselőinél. Ezek az iskolák központi szerepet játszottak a japán egyediségtudat kialakulásában, amelyet az idő előre haladtával egyre nagyobb mértékben szimbolizált a kokutai (,országtest”26) eszméje. Az átmenet természetesen összetett folyamat volt. A császári hatalom helyreállítása, egyfelől, szorosan kapcsolódott ahhoz a népi hiedelemvilághoz, amelyet szimbolikusan a sintó képviselt. ${ }^{27} \mathrm{~A}$,ritualitás és a kormányzat egyesítésének" (saisei icchi 祭政一致) gondolata szintén erősen kötődik a

22 Farkas 2016.

23 Lásd ehhez Szabó 2010: 142-143.

24 Sorai konfucianizmusához lásd Takó 2015.

25 Magyarul lásd Szabó 2014: 137-141.

26 A kokutai szó jelentéséről és jelentésének változásáról részletesen lásd alább. A terminus fordítása kapcsán számolnunk kell azzal a fogalmi aszimmetriával, hogy nem áll rendelkezésünkre olyan, általunk is jól definiált és érthető terminus, amellyel a kokutai visszaadható, így leggyakrabban a „nemzet” (nation) előtagot alkalmazzuk („,nemzettest”, „,nemzeti egység”, „national polity” stb.), amely jelentésében megközelíti ugyan a kokutai egyik jelentését, ám észben kell tartanunk, egyfelől, hogy a 國體 összetétel nem a japán ,,nemzettudat” létrejötte után kerül használatba, hiszen itt épp e tudatosság létrejöttének a folyamatában járunk, másfelől pedig, hogy nem a nation és megfelelőinek japán fordítása. A jelen tanulmányban igyekszem kizárólag akkor használni a „nemzet” szót, amikor ez a nyugati értelemben vett nemzetállam eszméjére vonatkozik. (A nation fordításaként Japánban viszonylag későn szilárdul meg a ma használt kokumin 国民 terminus. Ennek egyik oka, hogy a fordítási kísérletek a Meiji-kor első felében meglehetősen ingadozóak, az 1889-es alkotmány pedig a „népre” a shinmin 臣民 terminust vezeti be, mivel itt az uralkodó alattvalóiról van szó. A kokumin csak a második világháború után lesz általánossá; TSHJ: 107-108.)

Hogy a Meiji-korban a sintót „,politikai célokra használták és a japán nemzet etikai és morális szabályrendszerévé változtatták”, egyes értelmezők számára a hagyomány vallásos jellegének az elvesztését jelentette (Papp 2016: 207). 
Mito-gaku gondolkodóihoz, többek közt Aizawa Seishisaihoz 会沢正志斎 (1782-1863), aki még a XIX. század első felében, a sintót, valamint a szülőtisztelet és a hüség konfuciánus és egyben a bushi morál magját is alkotó erényeit összekapcsolva hívja fel a figyelmet a „,nevek kiegyenesítésének”, 28 vagyis az uralkodói hatalom helyreállításának a szükségességére - szembeállítva a japán hagyomány egységét a fenyegető keresztény térítéssel. Aizawa Shinronja 新論, bár 1825-ben íródott, 1857-ben vált ismertté, épp egy évvel azelött, hogy a bakufu megnyitotta Japán kapuit a nyugati kereskedelem előtt. ${ }^{29}$ „Aizawa értekezése erős lencsét szolgáltatott, melyen keresztül a világ, s benne Japán helye látható. Amit [rajta keresztül] láttak, a térítésért való versengéssel színezett világ volt.” ${ }^{, 30}$ Amikor tehát japán „egyediségtudatról” beszélünk, fontos hangsúlyozni, hogy az bár megelőlegezte a császári hatalom helyreállítását, a Meiji-megújulás során Japánba kerülő nyugati eszmék, így például a modern nemzetállamról alkotott, a Nyugaton ekkorra már nagy karriert befutó elképzelések hatására az 1870-es évek első felében sok tekintetben árnyalódott, hogy aztán már ezen eszméket is magába építve egyfelöl az államideológiában, másfelől azonban a japán filozófiai önreflexióban éledjen újjá. A kokutai eszme útja érzékletesen példázza a folyamatot, amelynek során az átalakulás a fordulópontjához ér. Aizawa a Shinron első, Kokutai 國體 címü szakaszában úgy fogalmaz,

„[a]z égi ős [Amaterasu napistennő] az égben van, s fényesen ragyog a földre, az égi leszármazottak [ti. az uralkodók] az alant [lévők] felé adják tovább az őszinteséget és a [szertartások szerinti] tiszteletet [seikei

28 A nevek kiegyenesítése, zheng ming 正名 a konfuciuszi tanítás egyik központi eleme, és eredetileg a neveknek a régi uralkodók által meghatározott jelentéséhez való visszavezetését, a névnek való megfelelést (vagyis nem a nevek helyes használatát, hanem a név és a megnevezett eredeti összhangjának a helyreállítását) jelentette (lásd Várnai 2010, föként 3-5; a konfuciuszi tanításhoz Lunyu XIII/3). Persze a klasszikus konfuciánus bölcselet számos eleme Japánban idegen lévén, az egyenes nevek tanítására való hivatkozás önmagában is „,bu zheng ming” 不正名, szembemegy az egyenes nevek tanításával - a hasonló szelektív hivatkozásra ugyanakkor számos példát találunk nemcsak a japán, de a kínai bölcselet történetében is. A Mito-gaku vonatkozó tanításának nagyhatású megfogalmazása Fujita Yūkoku 藤田幽谷 (1774-1826) Seimeironja 正名論. A kokutai, a nevek és a Mito-gaku gondolkodásának az összefüggéséhez lásd Harootunian 2007: 185-186.

29 Maxey 2013: 20.

30 Maxey 2013: 20. 
誠敬], ${ }^{31}$ így a rítusok [matsuri 祭] és a kormányzás [matsurigoto 政] egy és ugyanaz, ${ }^{32}$ [az égi leszármazott] égi feladatai [tenshoku 天職] között pedig a kormányzásban, s égi alkotásai [tenkō 天工] között az [ég] képviselet[é]ben egy sincs, mellyel ne az égi őst szolgálná. Az őst tisztelve s népére ragyogva eggyé válik az éggel." ${ }^{, 33}$

A „kormányzásra” használt korai japán terminus, a matsurigoto 政 a „rítus, ünnep” jelentésü matsuri 祭 és a „,dolog, ügy” jelentésü koto 事 szavak összetétele, és ez önmagában is jól tükrözi a két funkció eredendő egységét, amelyet természetesen megtalálunk a kínai uralkodó esetében, így a konfuciánus tanításban is. Az éggel azonosított ${ }^{34}$ Amaterasu napistennő unokájának adja az ország kormányzásának a feladatát, annak leszármazottai tehát Amaterasut mint ősüket és egyben mint az uralkodó felett álló egyetlen hatalmat, az eget szolgálják, tisztelik, és közvetítik akaratát a birodalom felé. Ez a felfogás itatja át a kokutai összetételt, amelyen Kínában eredetileg ,egy ország jellemzőit, államrendjét, éghajlatát és földrajzát értették". ${ }^{35}$ Aizawa esetében a jelentés szorosan összekapcsolódik ezzel - a ,jellemzők" azonban egyre inkább a belső sajátosságokra, elsősorban pedig az egyáltalában vett sajátosságok meglétére vonatkoznak. A kokutai az ország egységét és másoktól való különbségét jelképezi.

„Ha barbárokat [ $i$ 夷] táplálunk a Középső Birodalomban [chūgoku 中国, ti. Japánban $\left.{ }^{36}\right]$, az ég-alatti felbolydul, a népben káros csoportok

31 Tudniillik a szertartások és magatartásuk révén mintát szolgáltatnak az istenséggel és ezzel együtt a közösség többi tagjával szembeni megfelelő magatartásra. Ez a felülről lefelé, fokról fokra elképzelt tisztelettovábbítás szintén a klasszikus konfuciánus tanításból táplálkozik.

32 Lásd a szövegrészhez adott szerkesztői magyarázatot: Aizawa 1973: 53.

$33\ulcorner$ 天祖在天、臨照下土、天孫尽誠敬於下、以報天祖、祭政維一、所治之天職 、所代之天工、無一非所以事天祖者、尊祖臨民、既与天一矣 $[. .].\lrcorner /$

「天祖は天に在りて、下土に照臨したまひ、天孫は誠敬を下に尽くして、 以て天祖に報じたまひ、祭政これ一、治むるところの天職、代るところの 天工は、一として天祖に事ふる所以にあらざるものなし。祖を尊びて民に 臨めば、すでに天と一たり $[\cdots] 」$ (Aizawa 1973: 382./53).

34 Ebben az azonosításban is látszik, milyen szorosan fonódik össze a sintó és a konfuciánus gondolkodás.

35 Szabó 2014: 143. 28. jegyzet. Vö. López 2006: 131. A $t i$ 體 ,alak, forma” jelentéséhez lásd Karlgren 1996: 597i.

36 Az eredetileg Kínát - minden más területtel, vagyis minden más barbárok lakta területtel szemben - jelölő terminus Japánra való alkalmazását Beasley a Meiji-kor előtti Japán egységtudat példájaként említi. Összekapcsolható ezzel az a késő Tokugawa-kori 
jönnek létre, az emberek erkölcstelenek lesznek. Ha mindezt átgondoljuk, vajon a Középső Birodalom [Japán] leszünk-e, a Ming vagy a Qing [Kína], talán India, vagy épp a Nyugat? Mi is az ország teste? Nos, ahogyan a négy test[rész] [shitai 四体, ti. a fej, a törzs, a kezek és a lábak] nélkül nem lehet valaki ember, teste [karada 体] nélkül hogyan lehetne országgá az ország?"37

Mint Maxey hangsúlyozza, Aizawa nem arról beszél, hogy amit Amaterasu Jinmu tennōnak 神武天皇 adott, valamilyen már meglévő „egység” feletti uralom volt, vagyis ,nem egy eredeti nyelvi, faji vagy etnikai egységre utalt, amely elveszett vagy beszennyeződött", hanem a birodalom egységére, amelynek a „barbárok” csakis alattvalóivá válhatnak, vagyis ahelyett, hogy azok idéznének elő benne változást, nekik kell átalakulniuk. ${ }^{38}$ Amikor a bakufu vezetője, ,„a barbárokat meghódító nagy hadvezér” (seiitaishōgun 征夷大将軍) ezt a mechanizmust nem volt képes müködtetni, alkalmatlanná vált feladatára - nem felelt meg a nevének. Ebben az értelemben ugyanis a Nyugat ugyanúgy pusztán „,idegen”, vagyis „barbár” volt, ahogyan a megelőző év-

szokás, hogy Kínát - nyugati mintára - Shinának 支那 nevezték. Lásd Beasley 1984: $558,561$.

$37\ulcorner$ 養夷狄於中国、天下嘋嘋、民有淫朋、人有比徳、挙而大観之、果為中国耶 、明清耶、将身毒耶、抑西洋耶、国之為体其何如也、夫四体不具、不可以 為人、国而無体何以為国也」/「夷狄を中国に養へば、天下嗷嘋として、民 に淫朋あり、人に比徳あり。挙げてこれを大観すれば、果たして中国たり や、明・清たりや、将た身毒たりや、そもそも西洋たりや。国の体たる、 それ何如ぞや。夫れ四体具わらざれば、以て人となすべからず。国にして 体なくんば、何を以て国となさんや。」(Aizawa 1973: 388-389/69).

Érdemes megjegyezni, hogy az emberi test és az ország mint egység „testének” párhuzamát már a klasszikus kínai bölcseletben is megtaláljuk: a problémásan datálható, de minden bizonnyal egészét tekintve is legkésőbb az i. e. I. századból származó Guanziben 管子 például azt olvassuk: „A négy végtag és a hat út [ti. a testnyílások] alkotják az [ember] testét [shen zhi ti 身之體], a négy helyénvalóság [zheng 正, ti. az úr, az alattvaló, az apa és a fiú, nevüknek megfelelő müködésében] és az öt hivatalnok [wu guan 五官, ti. a korabeli hivatali hierarchia öt fö minisztere] az ország testét [guo $z h i$ ti 國之體]. Ha a négy végtag nem müködik, ha a hat út nem átjárható, ezt [testi] veszteségnek [shi 失] nevezzük. Ha a négy helyénvalóság nem helyénvaló [úr, alattvaló, apa, fiú nem felel meg a nevének - vö. Lunyu XII/11], ha az öt hivatalnok nem megfelelően végzi el hivatali teendöit, ezt káosznak nevezzük [luan 亂].” ( $「$ 四肢 六道, 身之體也。四正五官, 國之體也。四肢不通, 六道不達, 曰失。四正 不正, 五官不官, 曰亂。」Guanzi 1934: XXXI. [II/36. o.]; datálásához lásd: Rickett 2001: 15). 
századok során uralom alá hajtott népek. Japánnak, ahogyan Aizawa és köre látták, egyedivé kellett válnia, hogy a külső hatás ne kerítse hatalmába, ezt az egységet pedig a hagyományban látták, amelyben kiemelt szerepe volt a sintóval elválaszthatatlan egységben kezelt uralkodónak. Mindebből egyenesen következett, hogy amikor 1867-1868 fordulóján a hatalom hivatalosan is újra az uralkodóhoz került, a kokutai eszméje komoly szerepet kapott a régi-új kormányzat ideológiai alátámasztásában. Az egység, amelyet helyreállítottak, a ritsuryō 律令 rendszer VII. századi bevezetése óta hatotta át a japán hatalomszerkezetet, a Meiji-kormányzat pedig, írja Kitagawa, „minden modern hatású külső dísze ellenére a történelem mitologizálásának és a mítoszok historizálásának rá jellemző típusát [own brand] dolgozta ki". ${ }^{39}$ Számunkra itt a két oldal, a „külső” dísz és a „,belső” viszonya bír kiemelt jelentőséggel.

A Tokugawa-kor utolsó szakaszában, mint Aizawa példáján láttuk, az $i$ 夷 ugyanúgy az idegen - az országon kívüli - barbárokat jelentette, akik mint ilyenek, par excellence barbárnak tekinthetők. A sonnō jōi 尊皇攘夷 (,Tiszteld az uralkodót, üzd ki a barbárokat!") mozgalom képviselői számára mindenki betolakodó volt, akinek érkezése változással fenyegetett. A különbséget, amely e szélsőséges nézet képviselőinek a vélekedése és a korai Meiji-kori értelmiség Japán-képe között fennállt, jól szemlélteti Sakatani Shiroshi 坂谷素 (Sakatani Rōro 坂谷朗盧, 1822-1881) 1874-es írása („Az uralkodó tiszteletének és a barbárság kiüzésének magyarázata", Sonnō jōi setsu 尊王攘夷説), amelynek első felében egy tíz évvel korábbi, a sonnō jōi eszmét a legvehemensebben képviselő Chōshū hanbeli partnereivel folytatott beszélgetést idéz fel. Sakatani akkor úgy érvelt, bár a bakufu helyesen teszi, hogy megnyitja kapuit a Nyugat elött, ennek módja szolgaisága miatt elítélendő, amennyiben a bakufu úgy tesz, mintha csak kényszerből engedne a nyomásnak, hogy később üzhesse ki a barbárokat. Holott, mondta társainak Sakatani még 1864-ben,

,[b]arbárnak [ $i$ 夷] azokat nevezték, akik nem követték a kínai szertartásokat, a kínai utat. A barbár tehát a vademberek (yaban 野蠻) neve. Hogyan nevezhetjük öket [külföldieket/ nyugatiakat] barbárnak, ha kezdetben mi voltunk vademberek? [...] Hogy a szellemekról, a buddhákról, a holtakról [shinbutsuyūmei 神佛幽冥 ${ }^{40}$ ] szóló hitet keverik a kor-

39 Kitagawa 1974: 225.

40 A szóhasználat természetesen anakronisztikus, ha közvetlenül a Zhou-kor 周 (i. e. 1023 i. e. 255) végére vonatkoztatjuk, hiszen a buddhizmus ekkorra még bizonyosan nem 
mányzás dolgába, s átgondolatlan magyarázatok révén tisztelik [az uralkodót], már a Zhou dinasztia végi Zhang Hong 莀弘 idejére sem volt szokás. E tisztelet egyetlen módja nem más, mint hogy a minden országot átszövő, mindenki számára megfelelő utat választjuk, s saját barbár szokásainkat üzzük ki." ${ }^{41}$

Persze kérdéses, hogy Sakatani valóban így fogalmazott-e tíz évvel korábban - a Meiji-kor eleji fordulat utáni álláspontja azonban egyértelmü:

„[m]íg tisztelet és kiüzés [sonjō 尊攘] évekkel ezelőtt azt jelentette, kiüzni a [bakufu idegen hatalmak felé mutatott] talpnyalás[á]t és megnyitni a kikötőket, ma továbbra is azt, kiüzni a talpnyalást [a Nyugattal szemben], s létrehozni a nyilvános eszmecserét alsó és felső [rétegek] között [jōgekōgi 上下公議]." ${ }^{42}$

Vagyis: a Nyugat gondolkodás nélküli leutánzása helyett a nyugati vívmányok megfontolt elsajátítására van szükség. Így fordul a „más = barbár” megfeleltetés a „barbár = megtagadott saját” párhuzamba, miközben az 1870-es évek japán értelmisége megismerkedik a nyugati eszmékkel és újításokkal. Ezek között épp úgy megtalálható az öltöny és a szeparált fürdés, ahogyan a parlamentáris államszerkezet, az oktatás, a jog nyugati mintái vagy épp a nyugati értelemben vett modern Nationalstaat eszméjének és struktúrájának ,japánra” - azaz Japánra - fordítása.

Ez az egység lesz az egyik új jelentése a kokutai terminusnak Fukuzawa Yukichi 福沢諭吉 (1834-1901), a japán „felvilágosodás” egyik legnagyobb hatású gondolkodójának a munkáiban. Fukuzawa - e tekintetben egy véleményen a nyugati eszmékre építve Japán szellemi megújulásán dolgozó Meiji Hat Társaság (Meirokusha 明六社) legtöbb gondolkodójával - igyekezett a lehető legnagyobb mértékben elválasztani egymástól vallást és hatalmat, $\mathrm{s} a$ kokutai, a legitimáció és a leszármazás révén igazolni az uralkodói intézményt,

érkezett Kínába. Sakatani a saját korában elterjedt szófordulatot inkább általánosan „,istenségek” értelemben használja.

41 「夷稱ノ立ツ中國ノ禮アリ道アルガ如クナラザル

リ我先ヅ野蠻夕ル何ゾ彼习夷卜スル 得ン [...]神佛幽冥ノ教习以テ政二混ジ

不思議ノ説习以テ尊信习致ントスルフハ周末萇弘ノ時既に行レズ之ヨ尊フ

ノ方八唯萬國二貫通スルノ公正ナル道习以テシテ我夷タルノ習习攘フ二在

ノミ」(MRZ 43: 6).

$42\ulcorner[\ldots]$ 前年ノ尊攘八諂䛖习攘テ港习開クニアリ方今ノ尊攘八又諂䛖习攘テ上

下公議ノ方习定ムルニアリ」(MRZ 43: 9). 
ahol a kokutai a függetlenséget, illetve a nép tagjainak az összetartozását jelentette. ${ }^{43}$ Fukuzawa számára, írja Kōno, a kokutai „élesen megkülönböztetendő a politikai rendszer értelmében vett »kormányzati folytonosságtól« [...] vagy az »uralkodói vérvonaltól «". ${ }^{44}$ Igaz, Fukuzawa volt az egyetlen, aki a nyugati típusú megközelítés közvetlen, nationality ナショナリティ értelmében alkalmazta a kokutai fogalmát, a legtöbb „felvilágosító” (keimōsha 啓蒙者), így például Tsuda Mamichi 津田真道 (1829-1903) ugyanis ,az ország büszkeségét” (kuni no meiyo 国の名誉), illetve az ország belső szerkezetét értették rajta. Az azonban az 1870-es évek korai szakaszában általában véve sem volt jellemzö, hogy az uralkodói vérvonallal közvetlenül összekapcsolják a kokutait, mondja Kōno, olyannyira, hogy az egyetlen, aki többször utalt erre a vonatkozásra, a fent idézett Sakatani volt, a leszármazási folytonosságot azonban ő is elválasztotta az isteni származástól, a „Takama no harát idéző” (Takama no hara kusaku 高間之原クサク $)^{45}$ elképzelésektől ${ }^{46}{ }^{46}$ Vitathatatlan ugyanakkor, hogy a kokutai a legtöbb esetben továbbra is Japán egyediségére utalt. „Országunk teste [honpō kokutai 本邦國體], írja Sakatani,

„mivel az uralkodói leszármazási ág és az emberek szíve-elméje a kezdet kezdete óta egységet alkot, különbözik a tengerentúli országokétól, ezt pedig mindenki tudja, bármily kevéssé tanult is. [...] Akár kívánatosnak tartja valaki a nép által választott képviselőház létrehozását, akár, noha nem ellenzi, de korainak tartja, e vélekedésük egyaránt a birodalom [kōkoku 皇国] virágzását és erősödését, és az uralkodói leszármazási ág [ $k \bar{o} t \bar{o}$ 皇統] védelmét szolgálja." ${ }^{, 47}$

Mint látható, ,a szellemekről, a buddhákról és a holtakról” szóló hiteket a kormányzással összekapcsoló nézetek „kiüzése” korántsem jelenti az uralkodó tiszteletének a csökkenését, ahogyan nem jelentette azon igény elhalását sem, hogy Japánt egyedinek lássák. Azt a gondolkodói szituációt, amelybe a Japán értelmiség a Meiji-megújulással került, nem ezen igény eltűnése, hanem az egyediség egyértelmü voltának megingása jellemzi. Valóban úgy vélekedtek,

43 Craig 2009: 113-114; Kōno 2011: 149-150.

44「『国体』とは[...]政治体制としての『政統』[...]や、『国君の血統』とは鋭く 区別されるべきものである。」(Kōno 2011: 149).

45 MRZ 27: 4.

46 Kōno 2011: 150-151.

$47\ulcorner$ 本邦/國體開闢一姓統御人心固結シテ海外諸國卜異ナル苟モ少ク知覺アル 者皆之习知ル $[. .$.$] 今民選議院习起 7$ 欲シ及ビ之ヨ早トスル亦非トセザルノ人 モ亦其意必ズ之ヨ以テ皇國 7 富强ニシ皇統习保護セントスル」(MRZ 13: 6). 
hogy a Nyugat számos újítása elengedhetetlen az ország megreformálásához, és valóban felismerték, hogy a nyugati típusú államszerkezet kialakításának egyik sarokköve a hatalom és a vallás szétválasztása, ám továbbra is szükség volt valamire, aminek révén Japán belső egysége megôrizhető - valamire, ami úgyszólván „kitölti” a kokutai fogalmát -, méghozzá két okból. Szükség volt rá egyfelől azért, mert a Nyugatot megjárt japán gondolkodók számára világossá vált, hogy Európa nemzetállamai hasonlóak egymáshoz abban az értelemben, hogy bizonyos eszmék és meggyőződések legtöbbjükben egyaránt fontos szerepet játszanak, ugyanakkor ezen eszmék egyike épp az adott ország mint önálló, egyedi nemzet meghatározása volt. ${ }^{48}$ Japán egyediségének hangsúlyozására másfelől azért is szükség volt, mert az ezen egységre épülő magabiztosság feltétele volt a - Nyugathoz mért - fejlődés elöremozdításának.

Ismét elérkezünk ezzel a feszültséghez, amely abban rejlik, hogy az európai felvilágosodás nagyon is individualista alapeszméit Japán a sajátosan közösségcentrikus konfuciánus gondolkodás terminusaival interpretálta, és amely most ugyanezen individualista eszmék és a belső keletkezésü japán gondolkodás, elsősorban a sintó viszonyában merül fel. Egyéniség és közösségiség e feszültségének a megértéséhez érdemes röviden kitérni Maruyama Masao 丸山真男 (1914-1996) híres gondolatmenetére a „nyilvános” (kōteki 公的) és a „privát” (shiteki 私的) elválasztásának a hiánya kapcsán.

A Tokugawa-kort tárgyaló híres tanulmányában Maruyama amellett érvel, hogy a Song-kori konfuciánus gondolkodásban szoros egységet alkotó moralitást, amely az összesség és az egyén ellentétét nem ismerte, Ogyū Sorai a konfucianizmus ,átpolitizálásával” (seijika 政治化) két részre választotta szét. Ez a szétválasztás azonban a japán nép gyökereit kereső, Kínával szemben erős kritikát gyakorló kokugaku iskola tanításában újra egybeforrt, de immár nem abban az értelemben, hogy az egyéni szféra nem létezett, hanem úgy, hogy a Sorai-iskola számára teljességgel „nem-politikait (unpolitisch) [ti. a belső érzelmeket, naimenteki shinjō 内面的心情] összekötötte magával a politikával". 49 Maruyama itt ugyanazon jelenség eszmetörténeti alapjaira világít rá, amelynek társadalmi vonatkozásait 1946-os ultranacionalizmus-esszéjében feltárja. E munkájában úgy ír:

\footnotetext{
48 Lásd ehhez Anderson 2006: 96.

$49\ulcorner[\ldots]$ 国学は徂徠学における非政治的\{ウンポリーティシュ\}なものを逆に政 治に連続させるに至つたのである。」(Maruyama 1998: 178).
} 
„[m]ivel az állam a kokutaiba helyezi az igaz, a jó, a szép belső értékeit, magától értetődik, hogy sem a tudomány, sem a művészet nem létezhet másként, mint ezen értékektől való függésben. Ez azonban korántsem pusztán külsődleges, hanem belsö függés is. ${ }^{~} 50$

Maruyamának, meglátásom szerint, igaza van abban, hogy az említett két szféra nyugati típusú elválasztása legalábbis a második világháború végéig Japánban ténylegesen nem történik meg, ${ }^{51}$ ám a japán minta sajátosságainak megadható egy olyan olvasata is, amely szerint nem arról van szó, hogy „külső” és „belső” szétválasztása egyáltalán nem jön vagy nem jöhet létre. A szituáció ugyanis úgy is értelmezhetô, hogy Japán a lehető legnagyobb mértékben „importálja” a nyugati állam- és társadalomszerkezet alapeszméit, beleértve az állam mint egyénekből álló közösség egységtudatát - ám, mint minden európai nemzetállam, Japán is saját hagyományára építi a hivatalosan immár individuumként kezelt egyén összetartozástudatát. Csakhogy ez a hagyomány, mint Maruyama rámutat, nem pusztán nemindividualista, hanem kifejezetten az ellentétes póluson helyezkedik el. Ez az a feszültség, amelyben a Meijimegújulás tényleges átalakulása lezajlik, és amelynek során Japán nem Nyugattá válik, hanem nyugati értelemben válik Japánná: nemzeti jellegüvé, de saját - határozottan közösségcentrikus - hagyományaira építkezve. Erösebben fogalmazva: nem arról van szó, hogy az ellentmondás miatt nem történik valódi átalakulás, hanem hogy az átalakulás sajátos jellege az ellentmondás megtartásában, mondhatni, az ellentmondás rendszerszintüvé tételében rejlik. Nem olyan ez, mintha valaki egyik nap kimonót viselne, másnap pedig nyugati öltönyt, és még csak nem is olyan, mintha az öltönyt a kimonóra próbálná felvenni, hanem mintha az öltönyviselésnek egyszerre volna feltétele a kimonó elvetése és viselése is. A japán eszmetörténet persze bővelkedik a hasonló ellentmondásokban, és bővelkedik az ezek feloldására kidolgozott technikákban is. ${ }^{52} \mathrm{E}$ technikák révén a japán ,nemzet” úgy épült fel egyszerre a múlt

$50 「$ 国家が『国体』に於て真善美の内容的価值を占有するところには、学問も 技術もそうした価值的実体への依存よりほかに存立しえないことは当然で ある。しかもその依存は決して外部的依存ではなく、むしろ内面的なそれ なのだ。」(Maruyama 1995: 22).

51 Annak elemzésére itt nincs módom, hogy az általa Sorai munkáiból kiolvasott, végső soron „átmenetinek” bizonyuló szétválasztásuk valóban megtörtént-e.

52 Gondoljunk például arra, ahogyan Ogyū Sorai a szigorú piramishierarchiára épülő klaszszikus konfuciánus hatalomelmélettel támasztotta alá az uralkodó helyett de facto hatalmat gyakorló sóguni kormányzatot (Takó 2015). 
ellenében és a múlt alapjaira, hogy bizonyos elemeket kiemeltek e múltból, és azokon mint pilléreken emelték az új rend épületét. Ilyen elem volt a kokutai eszme, amely szorosan összeolvadt a császár személyével, aki pedig minden „nyugatisága” ellenére továbbra is a sintó hagyomány fö letéteményese volt. E hagyományt ugyanakkor, miközben az állami ideológia központi alkotóeleme, vagyis gyakorlatilag „államvallás” maradt, a klasszikus értelemben vett „vallási” régiótól elkülönítették, így engedve teret a vallásszabadság nyugati eszméjének. ${ }^{53}$

\section{Kultúra és történelem}

A kokutai példáján jól érzékelhető, hogyan igyekszik Japán elhelyezni magát az „idegenek” érkezésével kitáguló térben. Nemcsak hasonlóan fontos és szimbolikus jelentőségü, de a szó klasszikus értelmében vett filozófiai szemléletmódokhoz is szorosabban kapcsolódik azonban az a mód, ahogyan Japán elkezdi keresni helyét az időben - az emberi történelem idejében.

Mori Arinori 森有礼 (1847-1889) Amerikában kiadott művét a japán oktatásról jellemzően az angol nyelv (nem pusztán az írásrendszer) átvétele melletti, kortársainál sokkal egyoldalúbb érvei okán szokás idézni. Bármilyen vehemensen érvel is azonban az angol bevezetése mellett, a japán nyelv degradálása nem jelenti beszélői lekezelését. Az angol átvételére épp azért van szükség, írja, mert

„[i]ntelligens fajtánk [our intelligent race], mely buzgón keresi a tudást, arra irányuló vállalkozásában, hogy megragadja az alapvető igazságokat a nyugati tudomány, müvészet [art] és vallás kincsestárából, nem függhet a kommunikáció ilyen gyenge és bizonytalan eszközétől." ${ }^{\text {4 }}$

E sorok után kevéssel, a Japán történetét és sajátosságait bemutató hosszú előszó végén a nyugati naptár japán átvételéről ír, amely,,megújítja annak

53 Hardacre 2017: 399-400. Mint Hardacre megjegyzi, a Meiji Alkotmány hallgat a vallás és a kormányzat szétválasztásának kérdéséről, miközben a vallásszabadságot garantálja mindaddig, amíg az nem sért nemzeti érdeket. A vallás és a kormányzat szétválasztásáról már az 1870-es évek elején folyó diskurzushoz lásd Maxey 2013: 122-137. Fontos ugyanakkor, hogy az állam ,semlegessége” hamarosan megszünt, és a sintó a századfordulótól ismét hivatalos támogatásban részesült. Lásd Maxey 2013: 183.

Mori 1873: lvii. 
biztosítékát, hogy Japán mint nemzet [nation] csakis a legmagasabb törekvéssel és a legjobb szándékkal viseltet idegen barátaival való viszonyát illetően". ${ }^{55}$ A nyugati kalendárium átvételének e magasztos említése után áll az előszó keltezése a következő formában: „First Month, 1st, 2533 (January 1, 1873)”. Az i. e. 660-as év, ahonnan a 2533 esztendő számítható, természetesen Jinmu uralkodásának tradicionális kezdete - azé az uralkodóé, akinek „dinasztiája napjainkig nem szenvedett változást, $s$ így a legrégebbi a világon". ${ }^{56}$ Miközben tehát Mori olyan mértéket ér el a nyugati kultúra átvételének propagálásában, így például az angol nyelv bevezetése kapcsán, hogy azt amerikai kollégái is kritikával illetik, nem szünik hangsúlyozni Japán egyediségét, amelynek központi eleme az uralkodói hagyomány töretlensége. Ezt a tradíciót erősíti az a koncepció, amelyben az uralkodót egyre szorosabban kapcsolják majd isteni öseihez - a konfuciánus őstisztelet és a sintó alapjain álló koncepció, amely a Meiji-korban egyre inkább az államideológia középpontjába kerül. A Gergely-naptár átvétele nem egyszerüen azt jelentette, hogy a hónapokat és a napokat a nyugati mintának megfelelően tudták jelölni, hanem azt is, hogy Japán bekapcsolódott ugyanabba a történelembe, amelyet Nyugaton már évszázadok óta ez a naptár mért - de úgy kapcsolódott be abba, mint az egyik legősibb képviselője. Miközben azonban az uralkodói ház ősi volta egyértelmüen erősítette ezt a szempontot, mint Yanabu rámutat, az eljárás a konzervatív nemzetformálás nyugati technikája is volt, amennyiben

„a modernitás kezdetén [mi japánok] nem pusztán szavakat vettünk át a nyugattól, hanem politikai, társadalmi rendszereket is [...]. Amikor Itō Hirobumi 伊藤博文 a Japán Birodalmi Alkotmányt és más müveit kidolgozta, az »isteni jog politikájának « ${ }^{57}$ Lorenz von Steintől Bécsben tanult rendszerét vette át." ${ }^{, 58}$

\footnotetext{
55 Mori 1873: lviii.

56 Mori 1873: iv.

$57 \mathrm{Az}$,isteni jog” arra utal, hogy az uralkodó réteg - osztály - a társadalmi rendet isteni, vagyis megbonthatatlan eredetüként mutatja be. Lásd Nitzschke 1932: 71.

58 「近代の初めに、私たちは西洋からコトバを輸入しただけでなく、政治、社会 制度も輸入した $[\cdots]$ 。伊藤博文は大日本帝国憲法などを作つたとき、ウイ ーンでスタイン (Lorenz von Stein) から教わつた『神権政治』の制度をとり 入れた。」(Yanabu 2001: 125.) Lásd még Beasley 2007: 660.
} 
Nem a mintául vett nyugati szerzőkkel szemben, hanem éppen öket követve, ez esetben szó szerint, Stein tanácsára erősítette Japán a sintót, ${ }^{59}$ ezáltal a nyugati minta - a vallási háttér előtt felépülő egység mintája - szerint, ugyanakkor a saját hagyomány erősítése révén, amely az „idegen” befolyás megfékezését is szolgálta, szembe is helyezkedve a Nyugattal. Hasonló kapcsolatnak köszönhető az is, hogy Mori, amerikai útjáról hazatérvén, mérsékelte újító eszméit, ismét csak egy a korban nagyhatású európai gondolkodó, Herbert Spencer hatására. Mori, írja feljegyzésében Spencer,

„eljött, hogy a véleményemet kérje a japán intézmények újraszervezéséről. Konzervatív tanácsot adtam neki - szorgalmazva, hogy lehetőleg térjenek vissza egy olyan formához, amely nem haladja meg sokban a korábbit, s nem szerencsés megkísérelniük az ettől való nagymértékü eltérést."

Spencer később Kaneko Kentarōnak 金子堅太郎 írt levelében pontosítja a Morinak mondottakat. Az új intézményeket, írja,

„a régiekbe kell ültetni [should be grafted], ezáltal megelőzve, hogy a folytonosság megszakadjon [...], nem a régi újjal való felcserélésére van szükség, hanem a régi forma átalakítására fokozatosan növekvő mértékben." ${ }^{\circ 1}$

A Steinhoz és Spencerhez hasonló európai tekintélyek közvetlen, praktikus tanácsai persze csak az egyik okát jelentették annak, hogy a radikális lépések helyét egyre inkább átvette a graduális fejlődésbe vetett hit. Hasonlóan fontos összetevőt jelent számos - részben persze hozzájuk is kötődő - szemléletmód elterjedése a konzervatív Meiji-értelmiség körében. Ilyen volt például a biológiaievolúció-elméletnek a társadalmi folyamatokra való alkalmazása, a szociáldarwinizmus hatása, amelyet jól tükröz a Meiji-kor egyik meghatározó konzervatív gondolkodója, Katō Hiroyuki 加藤弘之 (1836-1916) fejlődéselmélete. Katō az állam egységét - testét - az egyénéhez hasonlóan, de az egyénnél egyértelmủen magasabb rendủ individualitásként fogta fel, a „természeti törvények" (shizenhō 自然法) pedig számára nem az államok létrejötte elötti

59 Lásd Maxey 2013: 164; részletes összefoglalását Grünfeld 1913: 353. Érdemes megjegyezni, hogy maga Stein sikeresnek értékelte Japán Nyugathoz való csatlakozási kí-

60 sérletét (Caspar-Knatz-Otabe 2011: 9).

60 Idézi Duncan 2014: 161

61 Spencer levele 1892. aug. 21-én: Duncan 2014: 319. 
natural law, natural right értelmében vett szabályokat jelentették, hanem a darwini szelekcióelmélet alaptörvényeit: az egyenlőtlenséget és a létfenntartásért folytatott küzdelmet. ${ }^{62}$ Arra a kérdésre tehát, miért fordítja Katō Bluntschli Naturrechtjét seihōként 性法 (a konfuciánus emberi alapbeállítódás értelmében vett ,természet” törvényeként) shizenhō 自然法 helyett annak ellenére, hogy a shizen kifejezés már használatos a nyugati értelemben vett „természet” (Natur) megfelelőjeként, ${ }^{63}$ csak részben nyújt választ Katō klasszikus konfuciánus elköteleződése. A magyarázat másik eleme ugyanis épp egy nagyon is modern meggyőződés, tudniillik az, hogy az egyetlen „törvényszerüség”, amely az emberben müködik, csakis a fennmaradás érdekében folytatott küzdelem ösztöne. E nézetnek az állam vonatkozásában is igen világos megfogalmazását találjuk Katō 1912-es Shizen to rinri 自然と倫理 (Természet és etika) címü munkájában. „Noha Hobbes és Rousseau uraktól kezdve”, írja,

„a szerződéselméletek képviselői úgy gondolták, bármiféle állam [kokka naru mono 國家なるもの ${ }^{64}$ ] a nép szerződéséből jön létre, az állam egyáltalán nem egy ehhez hasonló, emberek által létrehozott dolog. Sokkal inkább egészen olyan módon jön létre, ahogyan sejt[test]ek [tansaibōtai 單細胞体] sokaságának összekapcsolódásából összetett testek [fukusaibōtai 複細胞体] keletkeznek, a mi emberek mint [ilyen] összetett testek természetes [shizenteki 自然的] összekapcsolódása révén. Másképp fogalmazva, miként a sejtek teljesen tudattalan módon [muishikiteki 無意識的], eredeti milyenségük [koyūsei 固有性] nyomán összetett testeket alkottak, az emberek mint [ilyen] összetett testek teljesen tudattalan módon, kizárólag eredeti milyenségük nyomán összekapcsolódva államot alkotnak." ${ }^{, 65}$

62 Lásd Davis 1996: 38-40; 68-73. Csak utalni tudok itt Katō 1874-es Kokutai shinronjára 国体新論, amelyben az itt elmondottakkal is összhangban hangsúlyozza, hogy a kormányzat(i forma) (seitai 政体) egyértelmüen másodlagos a kokutaijal szemben, amennyiben ,,[a] kokutai a fő cél [ganmoku 眼目]. A kormányzat e fö cél elérésének módja" (Katō 1984: 405).

63 Takó 2017: 175-177.

64 A ma általánosan az ,állam” (state) fordításaként használatos kokka 国家 terminus viszonylag későn vette fel mai jelentését - alapvetően az 1889-es Meiji Alkotmány születése után, amikor Japán „hivatalosan” is kokuminkokka 国民国家, „nemzetállam” lett. Ez elött a kuni 国 („ország”), seifu 政府 (,kormány[zat]”) és hosszabb összetételek is használatban voltak, meglehetősen rendszertelenül. TSHJ: 80-81.

65「[...]ホッブス氏やルーソー氏を始め民約論者の如きは凡そ國家なるものは 全く人民の契約から出来たものである抔と考へたのであるけれども國家は 
Ez természetesen nem jelenti, hogy az emberekben ne létezne morál - ez is olyasmi azonban, ami történeti fejlődésük során, hasonló módon a természet fenti értelemben vett törvényszerüségei nyomán alakul ki bennük. ${ }^{66}$

A konzervatív államjogi gondolkodás és a pozitivista-evolucionista tudományszemlélet mellett szintén a Meiji-kor első felében érkezett ugyanakkor Japánba a XVIII-XIX. század fordulójának európai gondolkodását meghatározó, a történelem folyamatát mint egységes, a kor Európája felé tartó fejlődésmenetként értelmező idealista történeti szemléletmód is, amely szintén sajátos színezetet kapott. A nyugati filozófia egyik legelső, rendszerezett öszszegzése Japánban a katalán-amerikai Ernest Francisco Fenollosa (1853-1908) szóbeli előadásaiban valósul meg, aki Spencer gondolkodásának elterjesztésében is fontos szerepet játszott. ${ }^{67}$ Fenollosa, mint Yamaguchi hangsúlyozza, ${ }^{68}$ elsősorban nem Hegel, hanem az amerikai Hegel-interpretáció alapján és a spenceri evolucionizmussal is szoros egységben mutatja be azt a fejlödéselméletet, amely eredeti hegeli formájában arra az alapvető sémára épült, amely szerint a Szellem szabaddá válásának folyamata a Kelettel mint kiindulóponttal kezdődik, és a Nyugaton, végső soron a germán világban ér tetőpontjára. Az elmélet egyik kulcsfontosságú mozzanata ennek nyomán a „történelem végéről" szóló gondolat, ${ }^{69}$ amely nem azt jelenti, hogy az események sora Európával ténylegesen megszakadna, hanem azt, hogy a Szellem kifejlődésének folyamatában egy ponton túl nem történik további lépés. Hogy a német idealizmus ezen óriási hatású gondolkodójának rendszerét egy katalánamerikai angol nyelvű előadásai révén ismerte meg a nyugati gondolkodás iránt érdeklődő japán értelmiség, önmagában is igen különleges példája annak, ahogyan a különböző kultúrkörök gondolkodása az események sajátos összjátéka folytán egymásba fonódik. Számunkra azonban az is nagy jelentő-

\footnotetext{
決して左様なる人為的のものではなくして矢張單細胞體の衆多の集合から 複細胞体の成立するのと全く同様なる道理で複細胞體たる吾吾人間の自然 的集合で以て成立したものである換言すれば單細胞體が全く無意識的に其 固有性からして相集合して複細胞體組成したと同様に複細胞體たる人間が 全く無意識的に唯其固有性に依て相集合して國家を組成したのである。 (Katō 1912: 128).

66 Lásd Davis 1996: 54.

${ }^{67}$ Az evolucionizmus japán recepciója kapcsán vö. Kuwaki 2008: 93-96; Kumagai 1995: 66-71.

68 Yamaguchi 2015: 214. A fenollosai értelmezés Bowenhez való kötődéséről lásd Yamaguchi 2011.

69 Hegel 1979: 192.
} 
séggel bír, hogy a Fenollosa Hegel-értelmezésének alapját nyújtó Francis Bowen olvasatának, aki, mint írja, „nem kritizálni, hanem értelmezni” akarja Hegelt, ${ }^{70}$ mégis részét képezi a hegeli rendszer mint önmagában zárt rendszer kritikája, amennyiben a fejlődéskoncepcióból csak a folytonosságot fogadja $\mathrm{el}$, a történelem vége gondolattal fémjelzett lezártságot nem. ${ }^{71}$ Ez természetesen igencsak vitatható ,szakmai” szempontból, számunkra azonban azért különösen fontos, mert az újraértelmezés hozzájárult ahhoz, hogy Hegel koncepciója látszólag önellentmondás-mentesen legyen alkalmazható a Kelet, ez esetben Japán kontextusában. Feltehetőleg ez a megközelítés is hozzájárult ahhoz, hogy a fent idézett Sakatani Shiroshi fia, Sakatani Yoshirō 坂谷 芳郎 (1863-1941), Fenollosa előadásainak egyik hallgatója néhány évvel később így fogalmazzon befejezetlenül maradó Nihon kokufüronjában 日本国 風論 (Japán sajátosságai):

„Mint maga Hegel mondja, a szabadság eszméje ${ }^{72}$ [jiȳu no ri 自由ノ理] Keleten születik, s ahogyan a Nap Keleten jön fel, s Nyugaton nyugszik le, Európában éri el tetőpontját [kiwamaru 極ル]. Erről kell részletesen beszélnem. A föld egy gömb. Így felölünk az Egyesült Államok a Kelet. Az Egyesült Államokból Európa a Kelet. Így a szabadság eszméje Ázsiában születik, eljut Európába, majd Amerikába, s végül újra visszatér hozzánk a Keletre, így az eszme minden földet elér."ᄁ3

70 Bowen 1877: 362 .

71 Uo.

72 Vagy a szabadság rije - ebben az esetben Yamaguchi nyomán választottam az „eszme” megfelelöt, aki a szakaszt német fordításban idézi, és a ri ekvivalenseként az „Idee”-t adja meg (Yamaguchi 2015: 210). Ettől függetlenül beszédes a rivel való azonosítás és ezen keresztül a konfuciánus tradícióval való összekapcsolás.

73 「イゲル自ラ称テ曰ク、自由ノ理ノ東洋二起ル、日ノ東二昇リテ商二没ス ル如ク、欧洲二至リテ極ルト。余ハ将二之习敷延シテ言ハントス。世界八 円体ナリ。故二我ヨリ言へバ米国東洋ナリ。米留ヨリ言へバ欧洲東洋ナリ。 故二自由ノ理、亜西亜二起り欧洲二至り米国二渡り、遂二再ビ回リテ我大 東二至り、其理完全/地二達入卜」(Idézi Nozaki 2002: 11.)

Nozaki a német nemzetgazdaságtan nagy alakja, Karl Rathgen recepcióját vizsgálja Sakatani gondolkodásában. Erre az összefüggésre a jelen tanulmány keretei között nincs módom kitérni, fontos azonban, hogy a Nationalökonomie is olyan, viszonylag újkeletü nyugati tudományág volt, amely a nemzeti sajátosságokat a gazdaságtannal kötötte össze, a nemzetállamot pedig az élő szervezethez hasonlóan kezelte. 
Aligha szorul magyarázatra a Hegel történelemszemléletétől való gyökeres eltérés, ha összevetjük e sorokat a jelen tanulmány elején röviden már idézett hegeli szöveghellyel:

„A világtörténelem keletről nyugatra megy; mert Európa teljességgel vége a világtörténetnek, Ázsia a kezdete. A világtörténet számára egy

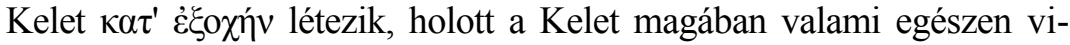
szonylagos; mert noha a föld gömb, a történelem mégsem kört ír le körülötte, hanem inkább meghatározott Kelete van, s ez Ázsia."74

A fejlődésmenetet tehát, amelyet Hegel par excellence egyvonalúként és lezártként kezel, Sakatani tudatosan, de éppen Hegelre hivatkozva relativizálja. A Kelet - ez esetben elsősorban Japán - ezáltal egyszerre lesz kiinduló- és végpontja a világtörténelemnek.

Mint e példák mutatják, mind a szó szorosabb értelmében vett politikai gondolkodás, mind a szigorúbb értelemben véve tudományos történelemszemlélet, mind pedig a filozófiai megközelítés terén felfedezhető a Meiji-Japánban az arra való igény - és egyben az abban való hit -, hogy az ország fokozatos történeti fejlődés révén kapcsolódjon be az európai gondolkodók által a felvilágosodás óta „,világtörténelemnek” vagy az „emberiség történelmének” nevezett folyamatba. Japán ugyanakkor, mint láttuk, Japánként igyekezett e folyamat részévé válni, és ennek megfelelően olvasztotta saját hagyományába a Nyugattól tanult gondolkodási mintákat is, így ismét vissza kell térnünk ezen a ponton a fent említett feszültséghez.

Caspar, Knatz és Otabe a japán és a német esztétikai gondolkodás összehasonlítását célul kitüző munkájukban a Meiji-kori nyugatiasodást az „akkulturáció” és az „asszimiláció” kategóriáiban vizsgálják. Az akkulturáció, mint írják,

„tágabb értelemben a kulturális sajátosságok cseréjét jelenti két kultúra találkozása esetén. Szükebb értelemben azonban arra a folyamatra utal, amelyben, a két kultúra egyenlötlensége, illetve aszimmetriája folytán, a gyengébb, illetve kisebbségben lévő kultúra - részben önként, részben kényszer hatására - asszimilálódik az erősebbhez."75

Nem kell messzire nyúlnunk, hogy visszajussunk az Edward Said-i értelemben vett orientalizmushoz - de innen újra eljutunk a Morikawa által középpontba

\footnotetext{
74 Hegel 1979: 192.

75 Caspar-Knatz-Otabe 2011: 9-10.
} 
helyezett japán okcidentalizmushoz is. Miközben ugyanis a Meiji-kori átalakulás, a japán történelem mint történelem „kezdete” bizonyos értelemben valóban a nyugati sémához való ,asszimiláció” volt, Japán a többi, kisebbnagyobb súlyú kulturális elemmel azonos mértékben vagy talán még vehemensebben vette át a Nyugatra jellemző magabiztos egyediségérzetet is. Az ország, írja Elberfeld,

„modernné vált. Azt azonban, hogy mit is jelent modernnek lenni Japán számára, csak a japán modernség előre haladó kiépítése [Konstitutionsprozeß] során határozzák meg és dolgozzák ki. Az európai modernség egyes területeinek puszta átvétele révén Japán még nem fejlesztette ki saját modernségét. A Japán számára való modernség jelentése csak az európai modernség különböző területeivel való kreativ szembehelyezkedés révén jön létre."

E tekintetben döntő jelentőségü, hogy Japán a Meiji-megújulás első éveinek meghökkenése után nem pusztán ideológiai alapokon igyekezett „magára találni”: saját erejébe vetett hitét és magabiztosságát nagymértékben növelték azok a történelmi események, amelyek nyomán valódi hatalommá kezdett válni a kelet-ázsiai térségben.

„A Nyugat jóakaróan kíséri végig Japán »civilizálását«. Egy nép modern voltának egyik legfóbb kritériuma azonban a korabeli európai számára [!] nem az oktatási vagy a gazdasági rendszer, hanem egy nép ereje a katonai érvényesülésben. Az imperializmus korában világos, hogy ez a terület döntő mérceként szolgál. A Kína (1894/95) és Oroszország (1904/05) feletti katonai győzelem és az 1902-es Angliával kötött szövetség révén válik Japán »nagykorúvá« ['mündig'] a Nyugat számára.,"77

Azáltal, tehetjük hozzá, hogy a Nyugat számára „nagykorúvá” válik, Japán „nagykorú” lesz a saját szemében is. „Modernnek lenni kultúrnemzetként azt jelenti, legyőzni a gyengébbeket. Ezeket a szövegeket akkoriban Japánban is olvassák. ${ }^{, 78}$ Sajátos aspektusa jelenik meg itt az interkulturális filozófia gyakran boncolgatott problémájának, jelesül hogy ,inter-kulturalitásról beszélni egymástól elszigetelt, a maguk számára létező kultúrákat feltételezne",

\footnotetext{
76 Elberfeld 1999: 43.

77 Elberfeld 1999: 44.

78 Elberfeld 1999: 46.
} 
ami természetesen azt a veszélyt rejti magában, hogy „a kultúrákat esszencializáljuk, vagyis olyan változhatatlan lényeget rendelünk hozzájuk, amely radikálisan megkülönbözteti őket más kultúráktól". ${ }^{79}$ Nem szabad megengedni ugyanakkor azt sem, hogy a kultúrák kölcsönhatása folytán létrejövő dinamizmus és állandóan változó jelleg elhomályosítsa a kultúrák azon elemi sajátosságát, hogy igényt tartanak olyan alkotóelemekre, amelyek „,radikálisan megkülönböztetik őket más kultúráktól”, és amelyek számukra magától értetődő módon „pozitívan” értékelhető elemek. Igen érzékletes bizonyítékát nyújtják ennek az önaffirmáló szándéknak azok a szövegek, amelyeket különböző megközelítésmódokat alkalmazó japán gondolkodók írnak a századforduló nyugati olvasója számára. Ezek egyik legismertebb esete - amelyre itt ezért nem is térek ki részletesen - Nitobe Inazō Bushidōja, de szükebb értelemben „filozófiai” példát szolgáltat Inoue Tetsujirō 井上哲次郎 (1855-1944) 1909-es „Die japanische Philosophie” című szócikke, amely a Hinneberg szerkesztette Die Kultur der Gegenwart (A jelen kultúrája) címü sorozat általános filozófiatörténeti kötetében kapott helyet. Inoue azzal a tétellel nyitja az írást, hogy Japánban ,csak a külföldi filozófia és vallás bevezetése után beszélhetünk filozófiáról”"80 - ezen nem a Meiji-megújulás idején bevezetett nyugati gondolkodásmódokat érti, hanem a konfuciánus és a buddhista gondolkodás átvételét az első évezred közepe táján. (Jó példája ez annak is, ahogyan Inoue a „filozófia” szó használatával legitimálja a nyugati mintától nyilvánvalóan óriási mértékben eltérő hagyományokat „filozófiaként”.) A rövid tanulmány ezeket az irányzatokat veszi sorra meglehetősen hézagosan, egészen rövid kitekintéssel a nyugati filozófia meghonosítására. Számunkra viszont a második bekezdés némiképp homályos és gyakorlatilag folytatás nélküli gondolata bír kiemelt jelentőséggel, amely szerint azt, hogy Japánban csak a külső eredetü gondolkodásmódok esetében beszélhetünk filozófiáról,

„nem szabad úgy felfogni, mintha a japán filozófiának nem volna eredeti, belső keletkezésü gondolati alapja [...]. Japánban régtől fogva létezett egy sajátos, ezen országot jellemző szellemi áramlat, amely több mint 2000 éven át volt tevékeny a nép általános érzületeként. E szellemi áramlat, melyet általánosan „Yamatodamashii”-nak, németül: a japán népszellemnek [der japanische Volksgeist] neveznek, alkotta a törzset [Stamm], melybe beoltották ama két külföldi gondolatrendszert, a kínai

79 Weidtmann 2016: 40.
Inoue 1909: 100. 
filozófiát és az indiai vallást, amelyek a korai időkben Japánt megtermékenyítették." ${ }^{, 81}$

Ami tehát a nyugati közönség számára ,japán filozófiaként” értendő hagyományt illeti, mondja Inoue, ez külső keletkezésü volt, van azonban valami, ami önmagában ugyan nem tartozik e „filozófia” körébe, nélküle mégis elképzelhetetlen volna ennek meghonosítása. Ez a meghatározatlanul hagyott dolog kimeríti a Volksgeist - nagyon is filozófiai és nagyon is „nyugatias” - fogalmát, hátterében pedig joggal sejtünk valami olyasmit, ami legalábbis szerves része, ha nem alapja a kokutai eszméjének is.

Mint látható, a nyugati értelemben vett „filozófia” igénye - beleértve nemcsak a filozófia müvelésének igényét, hanem azt is, amely a filozófiai gondolkodás gyökereinek a saját múltból való kimutatására irányul - a Meiji-kor eleji öneszmélés korszakában lépett fel. Jól tükrözi ez a filozófiai gondolkodás azon jellegzetességét, hogy ennek igénye egyenlő a tudatos önreflexió tudatos igényével. Természetesen az élet szabályozására, az emberben lévő erős hajlamok korlátozására, a társadalom müködésének szervezésére, az embereket körülvevő dolgokkal, lényekkel, jelenségekkel való harmónia kialakítására összpontosító, évezredek óta alakuló kelet-ázsiai bölcseleti hagyományok is „,reflexiót” jelentettek - nem határozták azonban meg magukat e reflexió tudatos és tudományos eszközeként, mert elsősorban nem kérdésekre és főként nem az emberi létezést és a társadalmi létet érintő általános kérdésekre adandó válaszokat kerestek, hanem bizonyos problémák megoldását. A konfuciuszi tanítás nem arra a kérdésre épül, hogy milyen az ember vagy az emberi közösség, hanem arra a megfigyelésre, hogy a harmónia egyre inkább elvész az emberből és közösségéből - hogy az égalattiban káosz (luan 亂) uralkodik -, és a buddhista gondolkodás sem a lét milyenségének megértését tüzi ki célul, hanem azon probléma megoldását, hogy a lét szenvedésteli. A jelen vizsgálódás kontextusában ez a különbség ismét nem annyiban fontos számunkra, hogy a Meiji-kor elötti japán gondolkodásmódokat helyes vagy helytelen-e filozófiának neveznünk ezek megértése szempontjából, hanem annyiban, hogy ha filozófiaként kezeljük őket, akkor a Meiji-kori és ez utáni japán filozófia csak ,újabb” filozófiai iskolák kialakulása lesz, és ez elfedi azt a meghatározó szemléletváltást, amely nyugati hatásra és nyugati mintákat követve jelenik meg Japánban. Ez a szemléletváltás nem pusztán új koncepciók és az ezeket jelölő fogalmak átvételét jelenti, hanem újfajta önértelmezés

81 Inoue 1909: 100. 
megjelenését mind az ember önmagához és közösségéhez, mind e közösség más közösségekhez - vagy: a nemzet más nemzetekhez - való viszonyát illetően.

\section{A tükör}

A jelen tanulmány keretei között elsősorban az a célom, hogy rámutassak azokra a motivációkra és igényekre, amelyek nyomán Japánban kialakult a filozófiai gondolkodás sajátos, a „belső” hagyomány és a Meiji-megújulással átvett „nyugati” tradíció összefonódásából kialakuló ötvözete. Fontos mindazonáltal egy példán szemléltetnem, mit kell értenünk e hagyományok „ötvözetén”. E példa, Nishida Kitarō 西田幾多郎 (1870-1945) etikája, természetesen részletes elemzést kíván önálló monográfiák formájában, amelyekből sem a japán, sem a nyugati szakirodalomban nincs hiány. Itt pusztán egy-egy szakaszra és ezek számunkra a jelen keretek közt levonható tanulságára koncentrálok.

Nishida Kitarō filozófiája jellegzetes módon olvasztotta magába különböző „keleti” és „nyugati” gondolkodásmódok elemeit, olyannyira, hogy Elberfeld „az interkulturalitás gondolkodójának [Denker der Interkulturalität]” nevezi, hozzátéve: „gen[itivus] subj[ectivus] és obj[ectivus]”. ${ }^{82}$ A két szöveghely, amelyet a jelen kontextusban egymás mellé állítok, nem csak a kultúrák közötti összefonódásra mutat rá Nishidánál, hanem arra a többszörös visszacsatolásra is, amely gondolkodását áthatja.

Nishida korai fömüvében, a Zen no kenkyūban 善の研究 (A jó vizsgálata) egyaránt fontos szerepet játszik az arisztotelészi etika, a kanti ismeretelmélet, a hegeli fejlödésszemlélet, csakúgy, mint a keleti erénytani bölcselet és a buddhista gyakorlat - igaz, az utóbbi rá gyakorolt kulcsfontosságú hatását Nishida csak élete kései szakaszában ismeri el ${ }^{83}$ Számunkra itt a mű harmadik, magára a jóra (zen 善) vonatkozó szakasza bír kiemelt jelentőséggel ${ }^{84} \mathrm{~A}$,jót"

82 Lásd ehhez Elberfeld 1999: 61; Soós 2013: 18.

83 Suares 2011: 7; ill. uo. 86. 18. jegyz. Nishida azokon a helyeken is elsősorban nyugati szerzőkre, így például Wilhelm Wundtra, William Jamesre hivatkozik (lásd Nishida 1948a: 2-3), amelyeken egyértelmü a buddhista háttér, így például a tiszta tapasztalatról (junsuikeiken 純粋経験) szóló első szakaszban. Lásd még Weidtmann 2016: 227.

84 Természetesen fontos e szakasz összekapcsolódása az ontológiai alapokkal, önálló vizsgálatát azonban részben legitimálja, hogy Nishida eredetileg nem a Zen no kenkyū 
Nishida számos nyugati etikai tanítás kritikája ${ }^{85}$ után úgy határozza meg, mint az ember „maga-megvalósítása [jiko no hattenkansei 自己の發展完成], self-realization", 86 amely az akaratból (ishi 意志) indul ki. ${ }^{87}$ „Mivel”, írja, ez az

„akarat a tudatosság [ishiki 意識] legmélyebb egységesítő cselekvése [tōitsu sayō 統一作用], vagyis a[z ember] maga-mint-olyan [jiko sonomono 自己其者] aktivitása, az az eredeti szükséglet [yōkyū 要求] vagy ideál [risō 理想], amely az akarat forrása, szükségképp a[z ember] maga-mint-olyan sajátos jellegéböl [seishitsu 性質] jön létre, vagyis azt is mondhatjuk, a maga ereje [jiko no chikara 自己の力]." ${ }^{88}$

A ,jó” nem más, mint a „,szükséglet” (,,igény”, „vágy”89) kielégülése vagy az ideál megvalósulása, vagyis: önmegvalósítás. Miközben tehát a szakasz tetemes részét, mint mondtam, a nyugati etikai koncepciók kritikája teszi ki, röviden összefoglalva azon az alapon, hogy azok nem képesek általános mércét szolgáltatni a cselekvés értékeléséhez, Nishida saját etikai koncepciója is eszszenciálisan nyugati alapokra épül: egyfelöl a kanti fordulatra, amennyiben az akaratot a reflektált tapasztalásnál korábbra helyezi, de úgy, hogy eközben - Kanttól eltérően - nem a tiszta ész (az a priori tudás) és a tapasztalat szétválasztásából indul ki $;^{90}$ másfelől pedig az arisztotelészi eudaimoniára ( $k \bar{f} f u k u$ 幸福), az életben való teljes, általában való boldogulásra, ,jól-létre”, amelyhez az imént idézett fejezetben csatlakozik, ${ }^{91}$ rögtön megerősítve ugyanakkor a gondolatmenetet egy Konfuciusztól származó idézettel. ${ }^{92}$ Nishida a

végső egészében való megjelenésre szánta, és az előszóban utal rá, hogy a mű első olvasásakor az első szakaszt célszerü kihagyni. Lásd Soós 2013: 46.

86 Nishida 1948a: 224, az angol beszúrás az eredetiben.

87 Lásd ehhez Noda 1955: 347.

88 「意志は意識の最深なる統一作用であつて即ち自己其者の活動であるから、 意志の原因となる本来の要求或は理想は要するに自己其者の性質より起るの である、即ち自己の力であるといつてもよいのである。」(Nishida 1948a: 224). Soósnál „vágyakozás” - lásd Soós 2013: 44.

Nishida későbbi, kifejtett öntudat (jikaku 自覚) fogalma kapcsán lásd Mine 2011: 49.

Nishida 1948a: 222.

Az eudaimoniához lásd Arisztotelész 1225a; az idézett Konfuciusz-szakasz: Lunyu VII.15. („Ha durva ételeket eszem, vizet iszom és behajlíto[tt] karom a párná[m], akkor is, ilyen körülmények között is boldog [le 楽] vagyok.” Tőkei fordítását a jelölt helyen módosítottam.) A Nishida által használt terminus, illetve a hivatkozott klasszikus mủvek között ugyanakkor aszimmetria áll fenn: a klasszikus kínai nyelvben a japánban kōfukuként ,jól-lét”-et jelentő xing 幸 és $f u$ 福 írásjegyek, ,jószerencsé”-t, illetve „boldogság”ot jelentenek (lásd Karlgren $810 a$,luck, fortunate”, $933 d-h$,happiness, blessing”), 
következőkben tovább halad az egyén szintjéröl, és a „társadalmi tudatosságról” (shakaiteki ishiki 社会的意識) szóló fejezetben a családon (kazoku 家族) keresztül eljut az ,államig” ( $k o k k a$ 国家) - ezen a ponton kapcsolódik a gondolatmenet jelen témánkhoz.

A családot követő szinten, mondja, ,tudatos tevékenységünk összességét egyesítve, egy személyiség [jinkaku 人格] megjelenéseként is tekintendő módon, az állam áll", ${ }^{93}$ amelyet sokan a közösség védelme érdekében létrehozott egységként fognak fel, mások a tagjait alkotó egyének fölé helyezik, de mindkét tábor képviselöi tévednek.

„Mi mint individuumok [wareware no kojin 我々の個人] egy társadalom sejtjeiként [saibō 細胞] fejlődünk ki. Az állam alapja [hontai 本体] a szellemünk [seishin 精神] gyökerét alkotó közösségi tudat [kyōdōteki ishiki 共同的意識] megvalósulása. [...] Az állam az egyes személyiségek egyesülése, az állam rendszere és törvényei így a közösségi tudat akaratának megvalósulásai (az ókorban ez a magyarázat Platóné és Arisztotelészé volt, a modern korban Hegelé)." ${ }^{, 4}$

Az ember mint a társadalom „sejtjeként” személyiséggé váló létező és az állam alapjának - vagy eredetének, hontai - mint a közösségi tudat megvalósulásának gondolata egyfelől ismét felidézheti a kokutai eszméjéről fent mondottakat, amely eszmét Nishida is magáénak vallotta, ${ }^{95}$ ás általában véve szorosan kapcsolódik ahhoz, a sinocentrikus kultúrkört alapvetően jellemző társadalomszemlélethez is, amely az egyént a közösség alkotóelemeként fogja fel. Ezzel

a konfuciuszi mondásban álló le(lo) „öröm”-öt (yue ejtéssel „,[szertartási] zenét”) (lásd Karlgren $1125 a-c$,joy, rejoice in”), a konfuciánus tanításnak megfelelően a külsővel való összhang értelmében, míg az eudaimonia ,a jó lélek tevékenysége”, vagyis belülről jövő, önmagáért akart tevékenység, sokkal kevésbé állapot.

93 「家族に次いで我々の意識活動の全體を統一し、一人格の發現とも看做すべ き者は國家である。」(Nishida 1948a: 251).

94 「我々の個人は $[\cdots]$ 一社會の細胞として發達し来つたものである。國家の本 體は我々の精神の根柢である共同的意識の發現である。 $[\cdots]$

國家は統一した一の人格であって、國家の制度法律はかくの如き共同意識の 意志の發現である（此説は古代ではプラトー、アリストテレース、近代では ヘーゲルの説である)。」(Nishida 1948a: 251-252). Vö. Hegel 1983: 257-258.§ (,[...] Az öntudatnak az érzület révén az államban mint lényegében, tevékenysége céljában és eredményében van a szubsztanciális szabadsága. [...]” [257.§]; „Az állam mint a szubsztanciális akarat valósága, amely az általánosságává emelt különös öntudatának sajátja, a magán- és magáértvaló ésszerü. [...]" [258.§]). 
szemben, míg e megközelítések az egyénre kizárólag mint a közösség tagjára tekintenek, Nishida - explicit módon hegeli alapokra helyezkedve - arról beszél, hogy a személyiség mint valami önálló megvalósulása csakis mint az állam tagjának a megvalósulása lehetséges. Nishida azonban nem marad a hegeli keretek között sem, a gondolatmenet - noha nem Hegel kritikájaként, de - ,visszatér a Keletre", azaz egy olyan kontextusba, amelyben a történelemnek (még?) koránt sincs vége, hasonlóan ahhoz a megközelítésmódhoz, amelyet korábban Sakatani Yoshirō kapcsán említettem. Miközben ugyanis Hegelnél a germán birodalom ${ }^{96}$ egyben a szellem útjának végét is jelenti, Nishidánál „,az állam, ahogyan ma ismerjük”, még csak

„az egyesült közösségi tudat legnagyobb megvalósulása, személyiségkénti megvalósulásunk azonban nem állhat meg itt, még nagyobbat kíván. Ez az emberiséget [jinrui 人類] egy csoportba gyüjtő emberi társadalom egyesülése [jinruiteki shakai no danketsu 人類的社会の団結]. Ez az ideál jelent meg Pál kereszténységében és a sztoikus iskolában. Ez az ideál azonban nem válik valósággá egykönnyen, ma ugyanis még a militáris béke [bushōteki heiwa 武将的平和] korát éljük. ${ }^{97} \mathrm{Ha}$ a történelem távoli kezdeteitől követjük az emberiség fejlődésének nyomát, nem az állam az emberiség végső célja. Ha az emberiség fejlődésének egységes értelemben vett célja van, az egyes államok közül mind a maga küldetésének [shimei 使命] beteljesítése érdekében emelkedik fel és bukik el (az országok történelme [mankokushi 万国史] a hegeli úgynevezett világszellem fejlődése). A valódi kozmopolitizmus [sekaishugi 世界主義] azonban nem azt jelenti, hogy az egyes államok eltünnek, hanem azt, hogy az egyes államok egyre erösebbé válva megmutatják jellegzetességüket, s hozzájárulnak a világtörténelemhez." 98

96 Vö. Hegel 1983: 354.§

97 Lásd ehhez Jones 2003: 529.

98「國家は今日の處では統一した共同的意識の最も偉大なる發現であるが、我々 の人格的發現は此處に止まることはできない、尚一層大なる者を要求する。 夫は即ち人類を打して一團とした人類的社會の團結である。此の如き理想は 已にパウロの基督[キリスト]教において又ストイック学派に於いて現われて居 る。併し此理想は容易に實現はできぬ。今日は尚武装的平和の時代である。/ 遠き歴史の初から人類發達の跡をたどって見ると、國家といふものは人類最 終の目的ではない。人類の發展には一貫の意味目的があって、國家は各其一 部の使命を充す為に興亡盛衰する者であるらしい（萬國史は、ーゲルの所謂 世界的精神の發展である）。併し眞正の世界主義といふは國家が無くなると 
A világtörténelem mint ,az úgynevezett világszellem fejlödése” természetesen ismét a hegeli szemléletmódot tükrözi. Az a különbség azonban, hogy Nishida e fejlődés későbbi menetéről beszél, amelybe ,,a keleti világ” - ahogyan Hegel a minden szintjén csakis egyszer álló világtörténelem első fázisát nevezte szintén bekapcsolódik, ez a különbség tehát önmagában elég ahhoz, hogy Nishida szemléletmódja esszenciálisan eltérjen a hegelitől, miközben arra valóban nagymértékben támaszkodik is.

Hasonló kettősség figyelhető meg Nishida bő két évtizeddel későbbi, „A Kelet és a Nyugat régiségének kulturális formája metafizikai nézőpontból” (Keijijoggakuteki tachiba kara mita tōyōkodai no bunkakeitai 形而上学的立場 から見た東洋古代の文化形態, 1934) címü rövidebb írásában, amelyben a Keletet és a Nyugatot mint a „nincs” ( $m u$ 無) és a „,van” ( $y \bar{u}$ 有) kultúráját állítja szembe abban az értelemben, hogy mit tesznek meg világszemléletük alapjává. ${ }^{99}$ Eközben az egyes korai kultúrák között további különbségeket is feltár: a görögséget mint filozófiai, az izraelit és az indiait mint vallási, a kínait pedig mint a Sittére (shitte シッテ), ,a rituális és világi szokásra [reizoku 禮俗]”100 épülő kultúrát határozza meg, amely meg is marad ebben a hagyományra épülő állapotában. Ezen aspektusok felől szemléletmódja ismét párhuzamba állítható a világtörténelem hegeli leírásával, ${ }^{101}$ igaz, annak egyik fő eleme, a történelem Keletről Nyugatra tartó menete már itt is kimarad belőle, és még inkább saját irányt vesz, amikor Japánra tér át. Saját kultúráját egyértelmúen a Kelethez tartozónak nevezi, mondván,

,[n]em tudom, hogy őseink honnan jöttek, s hogy népünk miként jött létre. Azt azonban mondanom sem kell, hogy a Kelet [tōyo 東洋] peremén országot [koku 國] létrehozó, s évezredeken át egyedi módon fejlődő japán nép kultúrája a Kelethez tartozik. Országunk kultúráját

认交意味ではない。各國家が益方強固となう各自方特徵を發揮し、世界の 歴史に貢献するの意味である。」 (Nishida 1948a: 252-253 - Kiemelés tőlem T. F.).

99 Attól függetlenül, mondja Nishida, hogy a Keletnek nincs a nyugati filozófiai értelemben vett metafizikai tudománya, metafizikai gondolkodásról itt is beszélhetünk. A Kelet és a Nyugat ilyen, metafizikai gondolkodás alapján történő megkülönböztetésének alapja Nishida szerint az lehet, mit tesznek meg a létezés (jitsuzai 実在) alapjának: a Nyugat, mondja a ,van”-t, vagy másképp fogalmazva a „,materiálist” (,alakkal rendelkezőt”, yūkei 有形), míg a Kelet a „nincs”-et, az „,immateriálist” (,alak-nélkülit”, mukei 無形) (Nishida 1948b: 257-258).

100 Nishida 1948b: 262.

101 Vö. Noda 1955: 349-350. 
[így] az általam a nincs gondolkodásmódjának nevezett [sajátossággal] szeretném jellemezni." 102

Azután azonban, hogy Nishida mind az indiai, mind a kínai kultúrával összekapcsolja a japánt, amelyekből az egyaránt átvett számos elemet, rátér a japán kultúra egyediségére, mely

abban rejlik, hogy érzületi jellegü [jōteki 情的], nem magán kívül szemléli az örökkévalót [eien 永遠], hanem magán belül mozog egyik dologtól a másikig, az időt nem meghaladja, hanem az időben halad elöre, ezért hasonlítható a monszunhoz. ${ }^{103}$

Japán monszunhoz való hasonlítása egybecseng Watsuji Tetsurō 和辻哲郎 (1889-1960) klímaelméletével, amelynek első teljes megjelenése az idézett tanulmánynál ugyan egy évvel későbbi, annak részei már korábban napvilágot láttak. Anélkül, hogy részletesen kitérnék Watsuji müvének elemzésére, fontos hangsúlyozni, hogy az aprólékosan kidolgozott klímaelmélet egyik kulcsfontosságú eleme Japán teljesen egyedi jellegének hangsúlyozása, különös tekintettel a Japánra jellemző érzelmi beállítódásra - igaz, Watsuji hangsúlyozza a sajátos kettősséget, amely abból ered, hogy Japánban a trópusi és a hideg égöv sajátosságai egyszerre érvényesülnek. ${ }^{104}$ Egészen szembeötlö azonban a hasonlóság Nishida és Watsuji Japán-képe között a Meiji-kort jellemző hüségeszmény tekintetében. Míg ugyanis Nishida a Manyōshūt 万葉集 idézve úgy fogalmaz, a Japánban

„legmagasabb erkölcsi erény, a hüség [chū 忠], abból a tiszta érzületből [junjō 純情] származik, mely szerint »tengereket járva süllyedjen bár vízbe, hegyi úton járva fú teremjen testemen, ha uralkodónk [ōkimi 大皇] mellett halhatok, mit is számít mindaz«"105

\footnotetext{
102 「我々の祖先は何處より来り、我々の民族は如何にして成立したかを知らな い。併し東洋の一端に國して幾千年獨自の發展を遂げた日本民族の文化は 、東洋的たることは云ふまでもない。私は私の所謂無の思想を以て我國文 化を特徵附けて見たいと思ふ。」(Nishida 1948b: 270).

$103\ulcorner[\cdots$ 我國文化の徳色はその]情的なるにあると云ふことができる、外に永遠 なるものを見るのではない、内に物から物へ移り行くのである、時を越え るのでははない、時の中に動き行くのであるモンスーン的と考へられる所 以である。」(Nishida 1948b: 273).

104 Watsuji 1962, föként 139-141.

105 「我國の最高の道徳たる忠も、純情の發する所、海行かば水漬く屍、山行 かば草生す屍、大皇の辺にこそ死なめ、顧みはせじといふにあうた。」
} 
- a Meiji-kort meghatározó sonnō eszmét Watsuji a Tokugawa-kori hüség (chū 忠) képzetével szembeállítva azt írja, az utóbbi

„,egyedül a feudális úr és alattvalója közti individuális kapcsolatot jelentette, nem vonatkozott az állam egészének egybetartozására [kokka no zentaisei 国家の全体性]. Így az uralkodó tisztelete [sonnō 尊皇], amely [az Edo-kor végén, a Meiji-kor elején] az állam egészének egybetartozásához való kapcsolódást jelentette, alapjában különbözik az Edo-kori hüségtől." "106

Nishida szemlélete mégis, mind kiindulópontját, mind végkövetkeztetését tekintve, lényegében tér el Watsuji klímaelméletétől. Japán - a kokutai - egyediségét, a japán kultúra sajátos jellegét ugyanis bár Nishida is hangsúlyozta, munkája záró soraiban, ahogyan 1911-ben a Zen no kenkyüban az államok kapcsán, ismét az egyedi kultúrák közösségeként létrejövő egységes ,világkultúráról" ír.

„[E]gyéni álláspontunk felől fejleszteni egyéni kultúránkat nem pusztán azt jelenti, hogy absztrakt módon külön irányba haladunk. Nem más volna ez, mint a kultúra tagadása. Annak révén, hogy a különböző kultúrák, miközben megvédik saját álláspontjukat, a világot közvetítöként használva fejlesztik saját magukat, kialakul a valódi világkultúra [sekaiteki bunka 世界的文化]. [...] Ha mélyen önmagunkba tekintünk, $\mathrm{s}$ megismerjük a másikat, rátalálunk az útra is, melyen tovább kell haladnunk."107

Ram Adhar Mall röviden, de plauzibilisen érvel amellett, hogy a hegeli rendszer feloldhatatlanul erős eurocentrikussága okán nincs ,,segítségünkre az

(Nishida 1948b: 273). Az idézet a Manyōshū 万葉集 4094. verse (ld. Manyōshū, IV. köt. 279-281), amely gyüjtemény önmagában is a japán kultúra ,aranykorát” fémjelző antológia szerepét tölti be a Meiji-kor óta. Lásd Shinada nyomán Morikawa 2013: 86-88.

$106\ulcorner[$ 忠は]封建君主とその臣との間の個人的関係をのみ意味して、国家の全体性 とかかわるところはなかつた。だから国家の全体性への帰属を意味する尊皇 は、本質的に江戸時代の忠とは異なるのである。」 (Watsuji 1962: 148 - Kiemelések az eredetiben).

$107\ulcorner[\cdots]$ 獨自の文化の立場から獨自の文化を發展し行くといふことは、唯抽象 的に個別的方向にのみ進むことではない。それは文化を否定することに外 ならない。種々なる文化が各自の立場を守りながら、世界を媒介として自 己自身を發展することによつて眞の世界的文化が形成されて行くのである。 […深く已を窮め又よく他を知ることによつて我々の進むべき途を知り得る のである。」 (Nishida 1948b: 284-285). 
interkulturális megértés és kommunikáció [formáinak] keresésében". ${ }^{108} \mathrm{Az}$, hogy Nishida gondolkodásában, ahogy a XIX-XX. század fordulóján számos más japán gondolkodónál is, komoly szerep jutott Hegel filozófiájának, egyfelöl arra is bizonyítékul szolgál, hogy még a Hegeléhez hasonlóan, nemcsak teljességük értelmében, de kulturálisan is zárt filozófiai rendszerek is alkalmasak rá, hogy kreatív módon kitágítva számukra eredetileg idegen szemléletmódok elemévé váljanak (erre számtalan példát találhatunk mind az európai, mind a sinocentrikus kultúrkör gondolkodástörténetében). Számunkra azonban ennél sokkal fontosabb egy másik mozzanat. Jelesül az, hogy Mallnak valójában igaza van: a hegeli filozófia egyáltalán nem olvasható ,interkulturális” megközelítésben a szó azon értelmében, ahogyan az interkulturális kommunikáció serkentését propagáló kortárs interkulturális filozófia a terminust bevezette. ${ }^{109}$ Minden olyan elmélet tehát, amely a világ különböző kultúráinak egységéről, a szabadság ázsiai kiteljesedéséről, Japán világtörténelembe lépéséről beszél, bármennyire nélkülözze is a kritikát Hegellel szemben, bármily pozitívan hivatkozzon is rá, a szigorú értelemben vett hegeli történelemfilozófiával összeegyeztethetetlen. „Mint Meiji-kori japán - mondja Jones Nishida közvetlenül érintett volt két intellektuális tradíció találkozásában, $\mathrm{s}$ tudatosan törekedett rá, hogy egységbe foglalja őket egy rendszerben, amely mindkettőt felöleli, de egyiket sem pusztítja el." ${ }^{110}$ Hogy ez a vállalkozás elvileg lehetséges-e, attól függ, mennyire szigorúan definiáljuk hagyományok „egybefoglalását” vagy „elpusztítását”. Egyértelmü természetesen, hogy Nishida a hagyományok szintézisére törekedett. Az is kijelenthető ugyanakkor, hogy Hegel filozófiája konzisztens módon nem szelektálható, aki tehát ebből a filozófiából bizonyos elemeket kiemel, valami mást hoz létre. ${ }^{111}$ Nishida esetében tehát, noha valóban beszélhetünk ,interkulturalitásról” a különböző sajátos kulturális elemek összekapcsolása értelmében, ez semmiképp nem kultúrák feletti vagy a különböző kultúrákba egyaránt illeszkedő gondolkodásmódot jelent. Nishida filozófiája csakis abban az értelemben volt ,,inter-kulturális”, hogy elemeit különböző kultúrákból emelte saját gondolkodásába -

108 Mall 2000: 49-52; itt: 52.

109 Lásd Mall 2000: 1-2.

110 Jones 2003: 529.

111 Nem maradhat említés nélkül ezen a ponton a feszültség, amely abból fakad, hogy ez a „más”, amely mégis magába olvasztja a hegeli rendszer számos elemét, hasonlóképp emeli magába (hebt auf) ezt a rendszert, mint ahogyan épp a hegeli szemlélet szerint a történelem egyes korszakai épülnek egymásból-egymásra - ugyanitt azonban ismét a hegeli rendszer és a benne kirajzolódó világtörténeti folyamat lezártságába ütközünk. 
és épp ebben a tekintetben szimbolikus példája és kiteljesedése annak a folyamatnak is, amely filozófiai síkon a Meiji-megújulással vette kezdetét, általában véve azonban - legalábbis - a japán írásbeliség kezdete óta tartott. Abban az értelemben tehát, hogy itt nem „Kelet és Nyugat találkozásáról” vagy a Kelet „nyugatiasításáról” (westernization) volt szó, ahogyan már-már közhelyszerüen, sokszor romantikus felhangokkal fogalmazni szokás - épp úgy nem, ahogy Shōtoku taishi 聖徳太子 (574-622) korában sem Japán ,sinizálása" kezdődött meg. Ami Japánban történt, sokkal inkább az egyes kívülről származó - korábban kínai, később nyugati - elemek beolvasztása volt a sajátba, amely saját természetesen ezek hatására folyamatos változásban volt, hordozói - egyben változtatói! - számára viszont ugyanúgy fenntartotta folytonosságát, mint az előző századok során. ${ }^{12}$ Erősebben fogalmazva, nem Japán nyugatiasítása vette kezdetét a Meiji-megújulással, hanem ,a Nyugat keletiesítése": a Nyugat vívmányainak módszeres szelekciója és tudatos felhasználása a saját hagyomány továbbképzésében.

\section{Japán (és a) Nyugat}

Előző tanulmányomban számos példán mutattam be, miként kötődik a Meijikor értelmisége minden ,nyugatiasító” törekvése mellett mégis igen szorosan évezredes konfuciánus gyökereihez. A jelen írásban e gondolatmenetet kibővítve arra a kérdésre kerestem választ, miként reflektál a Meiji-megújulás Japánja saját hagyományára, és miként igyekszik nyugati mintákat követve, de épp e mintáknak megfelelően a Nyugattal szemben meghatározni magát mint modern ,nemzetállamot”, középpontban a sintó tradíciójával és az ehhez szorosan kapcsolódó uralkodóeszmével. A fent kiemelt mozzanatokon keresztül láthatóvá vált, hogy Japán a XIX. századi Európához hasonlóan az egység, a csorbítatlan harmónia és folytonosság szimbólumaként tekint múltjára, de nem mint az ,emberiség” közös egységét szemléli ezt a régiséget, hanem épp ellenkezőleg, saját egyediségének bölcsőjeként. Továbbá, bár Európához hasonlóan elmaradottságot is felfedez e múltban, ahelyett, hogy - többek közt épp Hegelhez hasonlóan - a megkövült, változtathatatlan elmaradottságot látná e múlt meghatározó sajátosságának, éppenséggel a hagyomány magját alkotó, legősibb elemek megőrzése és a Nyugattól - de nem vagy csak lát-

${ }^{112}$ Vö. Zentai 2015: 19. 
szólag a Nyugat „kedvéért” - átvett elemekkel való kiegészítésében látja jövője zálogát. A hagyomány, a régmúlt egységének letéteményeseként és folytatójaként követel tehát helyet magának a szintén európai mintából kiindulva, de immár a Kelet perspektívájából szemlélt „,világtörténelemben”.

Noha a vizsgálat során számos alkalommal hangsúlyoztam a folytonosság szerepét Japán önértelmezésében, természetesen vitathatatlan, hogy a Meiji-kor mély és átfogó változást hozott, méghozzá nem pusztán külsődleges, hanem belső változást, amely azonban belső volt abban az értelemben is, hogy Japán nem lépett ki önmagából. Vannak, akik belenéznek a tükörbe, és elmenekülnek, mások összetörik a tükröt, megint mások megpróbálnak kivetkőzni önmagukból. Amikor Japán a Nyugat tükrébe nézett, bár több hasonló fázison átesett, végül éppen annak révén alakult át számos értelemben, hogy egyik lényegi sajátossága tekintetében velejéig a „régi” maradt: ugyanaz a páratlan adaptációs készséggel rendelkező kultúra, amely Shōtoku korában volt. Belenézett a tükörbe, és a nyugati eszmékkel, az ezeket jelölő fogalmakkal és az e fogalmakat tartalmazó szövegekkel együtt mintegy magát a tükröt is japánra - Japánba - fordította. Miközben a nyugati szemlélő könnyen úgy vélhette, Japán „nyugatiasodik”, az ország a nyugati Japán-képekből - a romlatlan természetközeliség pozitív és a gyermeki elmaradottság negatív képzeteiből egyaránt - létrehozott egy saját, ,japán Nyugatot”. A „nemzetállamiság eszméje” mármost, ha azon alapul, hogy az uralkodók kivétel nélkül Jinmu trónján ülnek, épp annyira „nyugati” eszme, mint a tian 天 által elrendelt „egyenlőség”. Japán tehát a Nyugat tükrébe nézve természetszerüleg saját magát látta meg.

\section{Elsődleges források}

Aizawa Seishisai 会沢正志斎 1973. „Shinron” 新論 [„Új értekezés”]. In: Imai Usaburō 今井宇三郎 et. al. (ed.) Mitogaku 水戸学 (Nihon shisō taikei [A japán eszmetörténet kompendiuma] 53). Tōkyō: Iwanami Shoten, 49-159/381-422.

Arisztotelész 1975. Eudémoszi etika. Nagy etika. [Ford. Steiger Kornél] Budapest: Gondolat.

Bowen, Francis 1877. Modern Philosophy from Descartes to Schopenhauer and Hartmann. New York: Charles Scribner's Sons.

Guanzi 管子 1934. (Kommentálta Dai Wang 戴望). Shanghai: Shang wu yin shu guan. Angolul: Guanzi. Political, Economic, and Philosophical Essays from Early China, Vol. 1 (Revised ed.) 2001. Ford., bev., jegyz.: W. Allyn Rickett. Boston: Cheng \& Tsui.

Hegel, Georg Wilhelm Friedrich 1979. Elöadások a világtörténet filozófiájáról. Ford. Szemere Samu. Budapest: Akadémiai. 
Hegel, Georg Wilhelm Friedrich 1983. A jogfilozófia alapvonalai. Ford. Szemere Samu. Budapest: Akadémiai.

Inoue Tetsujirō [Tetsujiro Inouye] 1909. „Die japanische Philosophie.“ In: Paul Hinneberg (ed.) Allgemeine Philosophie (Die Kultur der Gegenwart I/5.). Berlin - Leipzig: B.G. Teubner, 100-113.

Katō Hiroyuki 加藤弘之 1912. Shizen to rinri 自然と倫理 [Természet és etika]. Tōkyō: Jitsugyō no Nihonsha.

Katō Hiroyuki 加藤弘之 1984. „Kokutai shinron“「国体新論」[„Új értekezés a kokutairól”]. In: Uete Michiari 植手通有 (ed.) Nishi Amane. Katō Hiroyuki. (Nihon no meicho 日本の名著 [Japán mestermüvek] 34). Tōkyō: Chūōkōron, 382-407.

[Lunyu 論語] Confucius 2002. The Analects. Hong Kong: The Chinese University Press. (kínai-angol kétnyelvü kiadás) Ford. D.C. Lau. Magyarul: „Beszélgetések és mondások.” In: Tőkei Ferenc (ford., vál., jegyz.) 2005. Kínai filozófia. Ókor. I. kötet. Budapest: Magiszter Társadalomtudományi Alapítvány, 57-177.

Manyōsh $\bar{u}$ 万葉集 1964. Ed. Takagi Ichinosuke 高木市之助, Gomi Tomohide 五味智英, Ōno Susumu 大野晋 (4. kötet). Tōkyō: Iwanami.

Mori Arinori 1873. „Introducition.” In: Mori Arinori (ed.) Education in Japan. A Series of Letters Addressed by Prominent Americans to Arinori Mori. New York: D. Appleton and Company, iii-lvii.

MRZ: Meiroku Zasshi 明六雑誌 [Meiji Hat Folyóirat], 1-43. szám (1874-1875). Elérhető a Nihongoshi Kenkyū Shiryō 日本語史研究資料 [Japán nyelvtörténet-kutatási források] adatbázisban: http://dglb01.ninjal.ac.jp/ninjaldl/bunken.php?title=meirokuzassi Angolul: Meiroku Zasshi. Journal of the Japanese Enlightenment. Ford. William Reynolds Braisted. Cambridge - Massachusettes: Harvard University Press, 1976.

Nishida Kitarō 西田幾多郎 1948a. Zen no kenkyū 善の研究 [A jó vizsgálata]. Tōkyō: Iwanami.

Nishida Kitarō 西田幾多郎 1948b. „Keijijōgakuteki tachiba kara mita tōyōkodai no bunkakeitai”形而上学的立場から見た東洋古代の文化形態 [,AA Kelet és a Nyugat régiségének kulturális formája metafizikai nézőpontból"]. In: Nishida Kitarō Tetsugaku no konpon mondai - zokuhen 哲学の根本問題 - 続編 [A filozófia alapproblémái 2. kötet]. Tōkyō: Iwanami, 256-285.

Sakatani Shiroshi 坂谷素 [1874]. „Minsengiin wo tatsuru ni ha saki seitai wo sadamu beki no gimon”「民選議院ヨ立ルニハ先政体ヨ定ムベキノ疑問」[„AArról, hogy a népi parlament felállítása előtt a kormányformát kell meghatározni”]. $M R Z$ 13: 5-9.

Sakatani Shiroshi 坂谷素 [1875]. „Minsengiin hensoku”「民選議院変則」[,Rendhagyó népi parlament"]. MRZ 27: 3-8.

Sakatani Shiroshi 坂谷素 [1875]. „Sonnō jōi setsu”「尊王攘夷説 」[„Az uralkodó tisztelete és a barbárok kiűzése magyarázata"]. $M R Z$ 43: 5-9.

Watsuji Tetsurō 和辻哲郎 1962. „Fūdo”「風土」[„Klíma”] In: Watsuji Tetsurō zenshū 和辻哲郎全集 8. Tōkyō: Iwanami, 5-241. 


\section{Felhasznált másodlagos szakirodalom}

Anderson, Benedict 2006 [1983]. Imagined Communities. Reflections on the Origin and Spread of Nationalism. London-New York: Verso.

Anderson, Benedict 2002 [1998]. The Spectre of Comparisons. Nationalism, Southeast Asia and the World. London-New York: Verso.

Bitterli, Urs 1982. „Vadak” és „,civilizáltak”. Az európai-tengerentúli érintkezés szellemés kultúrtörténete. Budapest: Gondolat.

Beasley, W.G. 1984. „The Edo Experience and Japanese Nationalism.” Modern Asian Studies 18.4: 555-566.

Beasley, W.G. 2007. „Meiji Political Institutions.” In: Marius B. Jansen (ed.) The Cambridge History of Japan. Vol. 5. The Nineteenth Century. Cambridge: Cambridge University Press, 618-673.

Blocker, H. Gene - Starling, Christopher L. 2001. Japanese Philosophy. Albany: State University of New York Press.

Caspar, Norbert - Knatz, Lothar - Otabe Tanehisa 2011. „Kulturelle Identität. Kunst und Ästhetik in Japan und Deutschland." In Caspar, Knatz, Otabe (ed.): Kulturelle Identität und Selbstbild. Aufklärung und Moderne in Japan und Deutschland. Berlin: Lit, 3-14.

Craig, Albert M. 2009. Civilization and Enlightenment. The Early Thought of Fukuzawa Yukichi. Cambrdige (Mass.) - London: Harvard University Press.

Davis, Winston 1996. The Moral and Political Naturalism of Baron Katō Hiroyuki. Berkeley: Institute of East Asian Studies, University of California.

Doma Petra 2013. „Az Idegen vonzásában: Sadayakko és Matsui Sumako színészi (ön)definíciója a nyugati és a japán színházművészetben." Theatron: Színháztudományi Periodika 12.4: 74-91.

Duncan, David 2014. The Life and Letters of Herbert Spencer. Cambridge: Cambridge University Press.

Elberfeld, Rolf 1999. Kitarō Nishida (1870 - 1945). Das Verstehen der Kulturen. Moderne japanische Philosophie und die Frage nach der Interkulturalität. Amsterdam - Atlanta, GA: Editions Rodopi.

Farkas Ildikó 2016. „Modernizáció tradícióval - A japán példa.” In: Salát Gergely - Szilágyi Zsolt (szerk.) Kulturális hagyomány a modern Kelet-ázsiai államban. Budapest: L'Harmattan, 213-229.

Fung Yu-lan 1966 [1948]. A Short History of Chinese Philosophy. Ed. Derk Bodde. New York: The Free Press - London: Collier Macmillan Publishers.

Grünfeld, Ernst 1913. „Lorenz von Stein und Japan.” Jahrbücher für Nationalökonomie und Statistik 45.3: 354-361.

Hardacre, Helen 2017. Shintō. A History. New York: Oxford University Press.

Harootunian, H.D. 2007. „Late Tokugawa Culture and Thought.” In: Marius B. Jansen (ed.) The Cambridge History of Japan. Vol. 5. The Nineteenth Century. Cambridge: Cambridge University Press, 168-258.

Jones, Christopher S. 2003: „Ethics and Politics in the Early Nishida: Reconsidering 'Zen no kenkyū'." Philosophy East and West 53.4: 514-536. 
Karlgren, Bernhard 1996. Grammata Serica Recensa. Taipei: SMC Publishing Inc..

Kitagawa, Joseph M. 1974. „The Japanese "Kokutai" (National Community) History and Myth." History of Religions 13.3: 209-226.

Kōno Yūri 河野有理 2011. Meiroku Zasshi no seiji shisō. Sakatani Shiroshi to „, dōri” no chōsen 明六雑誌の政治思想. 坂谷素之「道理」の挑戦 [A Meiroku Zasshi politikai gondolkodása. Sakatani Shiroshi és az „ész” kihívása]. Tōkyō: Tōkyō Daigaku Shuppankai.

Kumagai Jirō 熊谷次郎 1995. „Taguchi Ukichi to Igirisu”「田口印吉とイギリス」 [„,Tagchi Ukichi és Nagy-Britannia”]. In: Sugihara Shirō 杉原四郎 (ed.) Kindai Nihon to Igirisu shisō 近代日本とイギリス思想 [A modern Japán és a brit gondolkodás]. Tōkyō: Nihon Keizai Hyōronsha, 60-82.

Kuwaki Genyoku 桑木㛜翼 2008. Nihon tetsugaku no reimeiki. Nishi Amane no „Hyaku isshin ron” to Meiji no tetsugakkai 日本哲学の黎明期. 西周の『百一新論』と明治 の哲学界 [A japán filozófia hajnala. Nishi Amane „Hyaku isshin ronja és a Meijikori filozófia]. Tōkyō: Shoshi Shinsui.

López, Josefa Valderrama 2006. „Beyond words: the "kokutai" and its background.” Història Moderna i Contemporània 4: 125-136. www.raco.cat/index.php/HMiC/ article/download/53279/61309 (Utolsó elérés: 2017.06.18.)

Mall, Ram Adhar 2000. Intercultural Philosophy. Lanham - Boulder - New York - Oxford: Rowman \& Littlefield Publishers, Inc.

Maruyama Masao 丸山眞男 1998. Nihon seiji shisōshi kenkyū 日本政治思想史研究 [Japán politikai eszmetörténet]. Maruyama Masao shū 丸山眞男集 5. Tōkyō: Iwanami.

Maruyama Masao 丸山眞男 1995. „Chōkokkashugi no ronri to shinri” 「超国家主義の 論理と心理」[,Az ultranacionalizmus logikája és lélektana”]. In: Maruyama Masao $s h \bar{u}$ 丸山眞男集 3. Tōkyō: Iwanami, 17-36.

Maxey, Trent E. 2013. The "Greatest Problem". Religion and State Formation in Meiji Japan. Cambridge (Mass.) - London: Harvard University Asia Center - Harvard Univ. Press.

Mine Hideki 嶺秀樹 2011. „Nishida tetsugaku to Kanto”「西田哲学とカント」[„Nishida filozófiája és Kant"]. In: Nihon Kanto kenkyū 12. Kanto to Nihon no tetsugaku. 日本カント研究 12. カントと日本の哲学. [Japán Kant-kutatás 12. Kant és a japán filozófia]. Matsudo: Risōsha, 41-57.

Morikawa Takemitsu 2013. Japanizität aus dem Geist der europäischen Romantik. Der interkulturelle Vermittler Mori Ōgai und die Reorganisierung des japanischen 'Selbstbildes' in der Weltgesellschaft um 1900. Bielefeld: transcript Verlag.

Niikura Takahito 新倉貴仁 2009. Nashonarizumu no chishikijin. Fukuzawa Yukichi to kōseisuru chikara”「ナショナリズムの知識人一福沢諭吉と構成する力」[,A nacionalista értelmiségi. Fukuzawa Yukichi és az alkotó erő"]. Nenpō Shakaigaku Ronsh $\bar{u}$ 年報社会学論集 22: 56-67.

Nitzschke, Heinz 1932. Die Geschichtsphilosophie Lorenz von Steins. Ein Beitrag zur Geistesgeschichte desneunzehnten Jahrhunderts.Historische Zeitschrift, Beihefte 26. Oldenbourg Wissenschaftsverlag GmbH. 
Noda Matao 1955. „East-West Synthesis in Kitarō Nishida.” Philosophy East and West 4.4: $345-359$.

Nozaki Toshirō 野崎敏郎 2002. „Kāru Ratogen to Sakatani shiron”「カール・ラートゲ ンと坂谷史論」[,Karl Rathgen és Sakatani történeti értekezése”]. Bukkyō Daigaku Sōgōkenkyü Kiyō 9: 1-22. archives.bukkyo-u.ac.jp/rp-contents/SO/0033/SO00330L017. pdf(Utolsó elérés: 2017.06.18.)

Papp Melinda 2016. „Some Reflections on the Use of the Concepts of 'Religious Consciousness', 'Faith', and 'Religion' in the Cultural Context of Japan.” In: Hamar Imre, Takami Inoue (eds.) Faith in Buddhism. Budapest: ELTE Buddhizmus-kutatás Központja, 205-218.

Rickett, W. Allyn 2001. „Introduction.” In: Guanzi. Political, Economic, and Philosophical Essays from Early China, Vol. 1 (Revised ed.). Ford., bev., jegyz.: W. Allyn Rickett. Boston: Cheng \& Tsui, 3-48.

Soós Sándor 2013. A zen mint filozófia, illetve a zen buddhizmus mint tudati háttér fogalmának vizsgálata Nisida Kitaró Dzen no Kenkjú címü írásának szemelvényei alapján. (Doktori értekezés, Debreceni Egyetem BTK) https://terebess.hu/zen/mesterek/ Soos_Sandor_Ertekezes.pdf(Utolsó elérés: 2017.06.18.)

Suares, Peter 2011. The Kyoto School's Takeover of Hegel. Nishida, Nishitani and Tanabe Remake the Philosophy of Spirit. Lanham - Boulder - New York - Toronto - Plymouth, UK: Lexington Books (Rowman \& Littlefield Publ. Inc.).

Szabó Balázs 2010. „Shushigaku - A Tokugawa Japán »hivatalos« filozófiája.” Távol-keleti Tanulmányok 2.1: 135-144.

Szabó Balázs 2014. „Idegenek a láthatáron: Tokugawa Nariaki felirata a shōguni kormányhoz 1853-ban." Távol-keleti Tanulmányok 6.1-2: 137-158.

Szabó Balázs 2016. Test és tudat. A japán harcmüvészeti filozófia hajnala. Debrecen: Torii.

Takó Ferenc 2013. „Leibniz Kínája”. In: Gellérfi Gergö, Hajdú Attila (szerk.) Eötvözet II. Az Eötvös József Collegium és az Eötvös Loránd Kollégium II. közös bölcsészkonferenciáján elhangzott elöadások. Szeged: Szegedi Tudományegyetem Eötvös Loránd Kollégiuma, 136-149.

Takó Ferenc 2015. „Distinguishing Names - Identifying Reigns: The Role of Ten/Tian in Ogyū Sorai's Bendō and Benmei." In: Melinda Papp (ed.) Encounters with Japan. Japanese Studies in the Viseg-rad Four Countries. Budapest: ELTE University Press Eötvös Loránd University, 223-253.

Takó Ferenc 2016. „A mozdulatlan elmozdítása. John Stuart Mill Kína-képéröl”. In: Doma Petra, Takó Ferenc (szerk.) ,Közel, s Távol” IV. - Az Eötvös Collegium Orientalisztika Mühely éves konferenciájának elöadásaiból, 2014. Budapest: Eötvös Collegium, 229-247.

Takó Ferenc 2017. „Fordítva. Nyugati társadalomfilozófiai koncepciók és terminusok »japanizációja« a korai Meiji érában.” Távol-keleti Tanulmányok 9/2: 151-187.

Tobin, Joseph J. 1992. „Domesticating the West.” In: J. J. Tobin (ed.) Remade in Japan: Everyday Life and Consumer Taste in a Changing Society. New Haven: Yale University Press, $1-41$. 
TSHJ 2013: Tetsugaku shisō honyakugo jiten 哲学・思想翻訳語事典 [Filozófiai és eszmetörténeti forditási terminusok enciklopédiája]. Ishizuka Masahide 石塚正英, Shibata Takayuki 柴田隆行 ed. Tōkyō: Ronsōsha.

Várnai András 1973. Az európai Ázsia-kép történeti alakulása a keleti utazások megindulásától a felvilágosodás koráig, a felvilágosodás Ázsia-elméletei - különös tekintettel Kinára. (Doktori disszertáció, ELTE Bölcsészettudományi Kar).

Várnai András 2010. „Az »egyenes nevek« és a »nemes ember« egyenessége. Konfuciánus nyelvértelmezés és értékelmélet.” Távol-keleti Tanulmányok 2.2: 3-26.

Várnai András 2015. „Leibniz Kína-képe.” Magyar Filozófiai Szemle 59.1: 78-102.

Weidtmann, Niels 2016. Interkulturelle Philosophie. Aufgaben - Dimensionen - Wege. Tübingen: A. Francke Verlag.

Yamaguchi Seiichi 山口誠一 2011. „Fenorosa kōgi »Tetsugakushi« shinshiryō wo megutte - Gedanke (shisō) no mondai” フェノロサ講義「哲学史」新資料をめぐって Gedanke (思想)の問題 」 [„Fenollosa »Filozófiatörténet« előadásainak új forrásairól - A Gedanke (gondolat) problémája"]. Hōsei Daigaku Bungakubu Kiyō 法政大学 文学部紀要 63: 1-14.

Yamaguchi Seiichi 2015. „Fenollosas Vorlesungen über die Geschichte der Philosophie - Hegel.” In: Yoichi Kubo, Seiichi Yamaguchi, Lothar Knatz (ed.): Hegel in Japan. Studien zur Philosophie Hegels. Wien: Lit, 209-222.

Yanabu Akira 柳父章 2001. „Goddo”wa kami ka jōtei ka「ゴッド」は神か上帝か [Kami vagy Shangdi-e ,, God”?]. Tōkyō: Iwanami Shoten.

Zentai Judit Éva 2015. „A tradicionális kínai és az európai koncepciók egyidejű alkalmazása a japán orvostudományban és anatómiában.” Kaleidoscope. Müvelödés-, Tudomány-és Orvostörténeti Folyóirat 2015:11: 12-22. 